\title{
『전경(典經)』「권지(權智)」편 연구
}

고남식 *

\section{- 국문요약}

이글은 『전경(典經)』의「권지」편(編) 구절들을 통해 권지의 의미를 살펴보고, 다른 편에 나타난 권지적 면모와『전경(典經)』 각 편의 장 (章)의 양상을 찾아보며, 나아가 「권지」편 각 구절들의 변모를『대순전 경』6판과 비교 대조하여 그 문헌학적 의미를 탐색할 목적으로 진행되 었다. 상제가 1871년 9월 19일(院) 전라도 고부군 우덕면 객망리(客됴⼟ 里)에 강세(降世)하여, 광구천하(匡救天下)하기 위해 천지인 삼계에 대 한 대(大) 권능(權能)으로 9년간 천지공사(天地公事, 1901 1909)를 행 하여, 인류에게 전북 모악산(母岳山) 대원사(大院寺)에서 연 상제의 천 지대도(天地大道)가 전해지고 연차적으로 도수(度數)를 맞춰 지상에 오 (五)만년 무량극락(無量極樂) 용화선경(龍華仙境)인 지상천국(地上天國) 이 이룩되어 가는 것은 상제가 보여준 권능(權能)을 근간으로 천지공 사가 삼계(三界)에서 완수(完逐)되기 때문이다. 또「공사」편만이 아니 라「교운」,「교법」,「제생」,「예시」편 등도 상제의 권능을 토대로 이루 어져 최종적으로 지상천국이라는 유토피아가 구현되는 내용을 보여주 고 있다. 따라서 각 편 구절들에 대한 상제의 권지를 토대로 한 고찰 은 『전경』에 대한 통괄적 접근이라는 면에서도 의미가 있다고 할 수 있다. 또한 이글은 앞서 진행된「행록」,「교법」, 「공사」,「교운」편 연구

* 대진대학교 교수, E-mail: nsko88@hanmail.net 
와 마찬가지로 『전경』「권지」편 1장과 2장 구절들에 대해『전경』 (1974)보다 앞서 1965년에 출판된 증산교단(酤山敎團)에서 보편화된 경전인 『대순전경』6판 구절들과 비교 분석하여, 「권지」편 구절들의 변이의 양상을 찾아보았다는 면에서도 연구의 의미가 있다. 이글에서 「권지」편 1장과 2장 구절들의 특성을 바탕으로『전경』각 편에 나타난 상제 권지의 양상을 찾아본 후 구절의 변이 양상을 『대순전경』6판과 비교 연구한 결과를 요약해보면 다음과 같다. 첫째, 상제의 권지는 천 지인 삼계에서 이루어져 천지공사(天地公事)를 통해 후천선경을 이루 는 핵심적 요소가 됨을 정리 요약된 구절들에서 볼 수 있다. 둘째, 『전 경』이 일곱 개의 편으로 나누어져 있지만, 「공사」편에 삼계 대권에 대 한 구절이 나타나듯이 일곱 개의 편에 천지인으로 용사된 상제의 권능 관련 구절들이 분포되어 각 편의 제목이 나타내는 목적을 이루는 것으 로 되어 있다. 이는 대표적으로 이글에서 본 「공사 편 1장 구절을 보 아도 드러난다. 셋째, 여러 개의 장으로 되어 있는 『전경』의 5 개 편에 서의 장의 분류에 대한 기준은 교법을 제외하고 공통점은 연도별로 이 루어졌다는 것이다. 「권지」편을 포함해서 다수의 장으로 이루어진 편 에서 내용상으로 보더라도 장 분류에 대한 규칙성은 특별히 찾을 수 없었다. 넷째, 『전경』「권지」편 1, 2장 구절들에 대해 이상호가 마지막 으로 편저한 『대순전경』의 최종판인 6판(1965)을 대비시켜 살펴 본 결 과 다음과 같이 크게 정리된다. 1 . 두 문헌에서 구절의 내용이 거의 같 은 구절도 있다. 2. 각 문헌의 서술이 단어(單語)나 몇 개 문장(文章)에 서 차이가 나는 구절들도 등장한다. 3. 각 문헌의 구절의 연도가 차이 가 나는 구절들이 보인다. 4. 기록의 내용상 두 문헌의 각각에서 더 추 가된 기록들도 발견된다.

주제어 : 권지(權智), 삼계대권(三界大權), 태양을 멈춤, 길을 다스림 


\section{I. 머리말}

II. 『전경』구절로 본 권지(權智)의 의미

III. 상제의 삼계대권으로 본「권지」편 구절 양상

IV. 「권지」편 외『전경』다른 편에서의 삼계대권의 양상과「권지」 편 장(章)의 분류 고찰

V. 「권지」편 구절의『대순전경』6판 구절과의 비교

VI. 맺음말

\section{I . 머리말}

구천상제1)(九天上帝, 九天應元雷聲普化天尊美聖上帝, 1871 1909) 는 우주(宇宙) 원시의 신성 - 불 - 보살들의 하소연으로 광구천하(匡救天 下)하고 후천(後天)의 선경(仙境)세상인 무량극락(無量極樂) 오만년 청 화지세(淸華之世)로서 무사지공(無私至公)의 지상천국(地上天國)을 이 룩하고자, 객망리(客望里)2)에 강세(降世, 院 1871.9. 19.)하여, '천지공 사(天地公事, 1901 1909)'의 성적(聖蹟)을 9년간 처결하고 화천(化天, 陰 1909.6.24)하였다. 이후 천지인 삼계(三界)에 후천선경(後天仙境) 이 이룩되는 것은 상제의 권능에 의해 물샐 틈 없는 도수(度數)로 짜 여진 천지공사가 이루어져가는 것이며, 이는 상제의 천지인에 대한 삼 계대권(三界大權)과 관련된 내용을 담고 있는 『전경』, 「권지」편 구절 들과 관계가 있다. 한편 주지의 사실로『전경』의 7 개 편인「행록(行 錄)」(총 5장),「공사(公事)」(총 3장),「교운(呚運)」(총 2장)3),「교법(教

1) 강증산(姜畺瓦山)의 존칭, 강일순(姜一淳), 강사옥(姜士玉)으로도 칭(稱)함.

2) 고부군 우덕면 소재. 
法)」(총 3장),「권지」(총 2장),「제생(濟生)」(총 1장),「예시(豫示)」(총 1 장)는 상제의 권지인 권능과 지혜에 따라 이루어진 상제의 성적(聖 蹟)이므로 권지와 무관할 수 없다. 이에 각 편에 나타나는 권지적 면 모를「권지」편 구절 내용을 토대로 고찰하는 면도 중요하다.

또한「권지」편(총 2장)은「행록(行錄)」(총 5장),「공사(公事)」(총 3 장),「교운(敎運)」(총 2장),「교법(呚法)」(총 3장)에 이어지는 다섯 번 째 편으로 두 개 이상의 장으로 구성된 편 가운데『전경』의 마지막 편이며, 이후「권지」편(총 2장)에 이어지는 『전경』의「제생(濟生)」(총 1 장)편과「예시(豫示)」(총 1장)편은 한 개의 장으로 되어 있다. 『전경』 에서「권지」편(총 2장)의 구성을 보면, 2개 장으로 편성(編成)되어 1 장은 총 33 절이고, 2 장은 총 38 절로 총 구절 수는 71 절이다. 『전경』 의 총 면수(面數)인 340면의 262면에서 289면까지로『전경』총 면수 에서 비교적 많지 않은 약 11 분의 1 인 27 면을 차지하고 있으나4) 권 지의 중요성은 『전경』 전 구절에서 그 양상이 나타나고 있는 면에서 찾을 수 있다.

『전경』과 상제 관련 문헌에 대한 기존 연구사를 보면, 기록에 대한 전승(傳承) 차원에서 김탁에 의해「증산교의 교리체계화 과정」5)이라는 논문이 발표된 이래로 임영창에 의한「대순전경』의 사적 의의」6)라는 글이 있었다. 「해원(解冤) 주제 강증산 전승 연구」라는 논문7)이 있었

3) 1 장은 구천응원뇌성보화천존강성상제(九天應元雷聲普化天尊姜聖上帝, 姜眮山, 姜一 淳, 姜上玉, 1871.9. 19. 1909.6.24.〈陰〉, 壽 39세)에 대한 기록. 2장은 구천응원 뇌성보화천존강성상제로부터 천부적인 종통을 전수(傳受)받은 조성옥황상제(趙聖玉 皇上帝, 道主, 趙哲濟, 1895. 12. 4. 1958. 3.6.〈陰〉, 壽 64세)에 대한 기록이다.

4) 이 중 1 장은 13 면이고, 2 장은 14 면이다.

5) 김탁, 「증산교의 교리체계화 과정」(한국정신문화연구원 석사학위 논문, 1986).

6) 임영창, 「대순전경의 사적 의의」『증산사상연구』 15 (1989).

7) 고남식, 「해원 주제 강증산 전승 연구 (건국대학교 박사학위 논문, 2003). 이 논문은 『전경』을 포함한 증산 관련 19 종의 문헌에서 해원과 관련된 주제를 선별해서 그 변이 의 양상 및 그 의미를 종교적 의의와 관련해서 논의한 것이다. 이후『전경』과 『대순 전경』 및 증산 관련 타 경전을 비교해서 연구한 논문으로는 강증산의 천지공사 이전 기록에 주목해서 논의한 고남식, 「천지공사를 중심으로 본 대순진리회『전경』과 증산 관련 경전의 경향 , 『신종교연구』 16 (2007)가 있다. 또 고남식, 「강증산 관련 경전의 변이에 대한 고찰-천지공사 이전의 내용을 중심으로, 『종교연구』50 (2008); 고남 
고 강증산 관련 최초의 문헌인 『증산천사공사기』에 대해 양은용은 「증 산교의 성립과 증산천사공사기」라는 논의를 하였다.8) 아울러『전경』 (1974)의「교법」편9)과「공사」편10) 및「행록」편11) 그리고「교운」편 1 장에 주목해서 그 내용을 살펴보고, 『대순전경』(1929 1965)과의 구절 내용의 변이와 차이점을 논의한 연구12)도 이루어진 바 있다.

이상의 연구사를 토대로 해서 본고는 종단 《대순진리회(大巡眞理 會)》의 소의(所依) 경전인 『전경』의 각 편에 대한 현재까지 진행된 연 구를 이어, 『전경』내에서 상제의 권능(權能)과 지혜(智慧)를 보여주는 '권지'의 의미와 그 용사(用事) 관련 내용들을 살펴보고 나아가 증산 교단에서 일반적으로 보편화된 전대(前代)의 『대순전경』6판(1965)구 절과의 변모 양상을 비교하여, 『전경』(1974)의「권지」편 기록을 중심 에 두고 기록상 변이를 고찰해보았다는 면에서 그 연구의 의의가 있다. 또한 이번「권지」편 연구에서 다른 편에서의 연구와 다른 면모는 「행 록」,「교법」, 「공사」,「교운」,「제생」,「예시」 등 상제의 권능(權能)과 지혜(智慧)가 『전경』 모든 편에서 기저(基底) 및 근원(根源)으로서 작 용하여 나타나고 있다는 면에서, 「권지」편 외에 「공사」편 1장에서 권 지적 양상을 살펴보았다는 점에서도 그 의미가 있다. 또 다른 하나는 『전경』의 각 편의 장의 구성 및 개수에서 2개 이상의 장으로 되어 있 는 편의 마지막 장이「권지」편인 점에 주목하여『전경』 각 편의 장의

식, 『대순전경』초판 구절의 변이 - 초판 10장을 중심으로, 『종교연구』 67 (2012); 고남식, 「대순전경』의 변이에 대한 연구, 『종교연구』75-1 (2015)가 있다. 이 맥락 을 이어 이 글은 『전경』의「권지」편과 증산 관련 타 문헌인 『대순전경』을 비교 연구 하였다는 면에서 여타 강증산 관련 문헌 연구와 차별성을 갖고 있음을 밝혀 둔다.

8) 양은용, 「증산교의 성립과『증산천사공사기』, 『한국종교』30 (2006) 이외에 관련 연구로는 다음과 같은 성과가 있다. 조동일, 『한국문학통사』4 (서울: 지식산업사, 1994), 근대이행기 문학 부분; 이대효, 『중세에서 근대로의 이행기 민중종교문학 연 구』(서울대학교 석사학위 논문, 1999).

9) 교법을 계율적 의미로 보고 대순진리회의 훈회와 비교하였다. 고남식, 『『전경』「교법 편 연구 -『대순전경』 6판「법언 장과의 비교를 중심으로」『대순사상논총』26 (2016).

10) 같은 성격 하의 두 개의 문헌의 편이 구절 상 어떠한 차이를 갖고 있는가를 검토하였다. 고남식, 『전경』「공사」편 연구」, 『대순사상논총』30 (2018).

11 ) 고남식, 『전경』「행록」편 연구」, 『대순사상논총』 32 (2019).

12) 고남식, 『전경』「교운」편 1장에 나타난 교운의 의미와 구절의 변이 연구」, 『대순 사상논총』 36 (2020). 
구성에 대해서도 일면 탐구해 보았다는 것이다. 이에 따라 이글의 각 장에서 살펴볼 내용과 과정은 다음과 같다. ㅍ장에서는 「권지 의 의미 를 권능(權能)과 지혜(智慧)로 나누어 『전경』구절 속에서 살펴보고, 이어서 III장에서는 「권지」편 1,2 장에서 각 구절의 의미를 요약적으 로 도표화하여 삼계대권(三界大權)이라는 맥락에서 분류하였다.13) 또 IV장에서는 다른 편에서 나타나는 권지와 관련된 삼계대권의 양상을 대표적으로「공사」편 1장을 통해 찾아보고14), 2개장으로 된「권지」편 의 장의 분류에 대해 2 개 이상의 장으로 되어 있는 다른 편의 장의 양상을 통해 비교해보았다. V장에서는「권지」편의 구절들을 문헌학적 으로 고찰한다는 면에서 각 구절을 『대순전경』6판과 대비해서 그 차 이가 나는 부분을 찾아 「권지」편 구절의 삼계대권과 연관된 의미 및 변이를 비교 분석해 볼 것이다.

이러한 연구를 통해「권지」편 구절에서 상제가 용사한 권능과 지혜 에 대해서 그 의미를 알아 볼 수 있을 것이며, 나아가 두 개의 장으로 되어 있는 「권지」편에 대해 다개(多個) 장으로 되어 있는 다른 편과 비교하여 장의 특성을 살펴보았다는 면에서도 의미가 있을 것이며, 이 를 토대로 편(編), 장(章), 절(節)의 상호 관계성을 다각도로 살펴보는 연구에도 향후 일조(一助)할 수 있을 것이라 사료된다.

\section{II. 『전경』구절로 본 권지(權智)의 의미}

권지(權智)는 '권(權)'에서 권능(權能)과 ‘지(智)'에서 지혜(智慧)로 나 누어 볼 수 있다. 『대순진리회요람』에는 ‘무상(無上)한 지혜(智慧)와 무

13) 삼계대권인 천계, 지계, 인계대권에 대한 분류에서 한 구절 안에 두 개의 권능이 관계되기도 함을 볼 수 있다. 이에 생각하기에 따라 분류에 있어 한 대권으로만 분 류되기 어려운 면도 있음을 밝혀 둔다.

14 ) 지면상「공사」편을 대표적으로 다른 편의 권지적 양상을 살펴보았음을 밝혀둔다. 
변(無邊)의 덕화(德化)와 위대(偉大)한 권능(權能)의 소유주이시며 역 사적 대종교가 이신 강증산(姜轠山) 성사(聖師)'15)라고 하여 상제에 대해 지혜, 덕화, 권능의 세 가지 면에서 기술하고 있는데, 권지(權 智)와 관련해서 권(權)은 '위대(偉大)한 권능(權能)' 그리고 지(智)에 대해서는 ‘무상(無上)한 지혜(智慧)'라고 기록되어 있기도 하다. 이장 에서는 상제의 권지와 관련해서 『전경』 구절을 중심으로 권능과 지 혜에 대해 포괄적 의미를 살펴보기로 한다. 권능(삼계대권) 관련 내 용을 보면 그 정의나 의미는「권지」편보다는 「공사」편에 더 많이 나 타나고 있다. 이는 다음의 구절에서 볼 수 있다.

시속에 말하는 개벽장은 삼계의 대권을 주재하여 비겁에 쌓인 신명과 창생을 건지는 개벽장(開䦣長)을 말함이니라. 상제께서 대원사에서의 공부를 마치신 신축(辛표)년 겨울에 창문에 종이 를 바르지 않고 부억에 불을 지피지 않고 깨끗한 옷으로 갈아입 고 음식을 전폐하고 아흐렛 동안 천지공사를 시작하셨도다.16)

위에서 신명과 창생을 건지는 개벽장(開䦣長)은 상제를 가리킨다. 상제는 삼계(三界) 즉 천계(天界), 지계(地界), 인계(人界)에 대해 위대 한 권능의 소유주이며 무상한 지혜를 지닌 구천의 상제로서 임의대로 권능을 보인 것으로 나타난다. 이는 상제가 개벽장이기에 삼계에 대해 대(大) 권능(大權)을 뜻대로 주재(主宰)하는 것이며 대원사(大院寺)17) 공부 후 최초 9 일간의 천지공사와 관계되어 이후에 9년간 천지공사가 상제의 권능을 토대로 전개되었음을 공사 편에서 볼 수 있다. 후천 개 벽의 주재자로서 상제는 낙원을 세우기 위해 천지 개벽공사(開闢公事) 를 행하였음을 다음과 같이 천명(閭明)하였다.

15)『대순진리회요람』(여주: 대순진리회 교무부, 2010), p.8.

16 ) 전경』(여주: 대순진리회 출판부, 2010), 공사 1장 1절(이하『전경』의 인용은 공 사 1 장 1 절의 경우 ‘공사 1-1'로 표기함).

17) 전북 김제시와 완주군의 모악산 소재. 
상제께서 이듬해 사월에 김형렬의 집에서 삼계를 개벽하는 공사를 행하셨도다. 이 때 상제께서 그에게 가라사대「다른 사 람이 만든 것을 따라서 행할 것이 아니라 새롭게 만들어야 하 느니라. 그것을 비유컨대 부모가 모은 재산이라 할지라도 자식 이 얻어 쓰려면 쓸 때 마다 얼굴이 쳐다보임과 같이 낡은 집에 그대로 살려면 엎어질 염려가 있으므로 불안하여 살기란 매우 괴로운 것이니라. 그러므로 우리는 개벽하여야 하나니 대개 나 의 공사는 옛날에도 지금도 없으며 남의 것을 계승함도 아니오 운수에 있는 일도 아니오 오직 내가 지어 만드는 것이니라. 나 는 삼계의 대권을 주재하여 선천의 도수를 뜯어고치고 후천의 무궁한 선운을 열어 낙원을 세우리라」 하시고...18)

위에서 상제는 부모의 재산이라는 비유적 예를 들어 오직 상제가 지어 만드는 전대 미증유의 금불문(今不聞) 고불문(古不聞) 천지대도 (天地大道)를 선언하고 있다. 여기에서 개벽(開閚)공사는 '선천의 도수 를 뜯어고치고 후천의 무궁한 선운을 열어 낙원을 세우리라'는 말처럼 무궁한 선운(仙運)의 유토피아를 세우기 위함인데, 상제는 '구천대원조 화주신(九天大元造化主神)'으로서 삼계(三界)에 대해 스스로 지어서 만 드는 대(大) 권능(權能)을 주재하였음을 알 수 있다. 무엇보다도 상제 가 소유한 '권(權)'인 삼계대권은 선천의 세상에서 상극으로 원한이 쌓 여 있는 삼계의 현실적 문제를 개벽하는 것이다.

선천에서는 인간 사물이 모두 상극에 지배되어 세상이 원한 이 쌓이고 맺혀 삼계를 채웠으니 천지가 상도(常道)를 잃어 갖 가지의 재화가 일어나고 세상은 참혹하게 되었도다. 그러므로 내가 천지의 도수를 정리하고 신명을 조화하여 만고의 원한을 풀고 상생(相生)의 도로 후천의 선경을 세워서 세계의 민생을 건지려 하노라.19)

위에서 삼계 대권으로 상제가 세상에서 이루어갈 새 세상은 1. 천지

18) 공사 $1-2$.

19) 공사 1-3. 
도수의 정리, 2. 신명의 조화, 3. 만고의 원한에 대한 해원, 4. 상생의 도에 의한 후천선경 수립을 통해 이루어짐을 알 수 있다. 이는 삼계에 대한 상제의 대권이 작용해가는 순서이며, 아울러 이 삼계대권의 용사 에는 다양한 요소들이 동원되며 통합적 삼계관하에서 유기적이며 역 동적으로 입체성을 갖고 천지의 신과 인계의 인간들이 총체적으로 하 나가 되어 상제의 권능 아래 참여했음을 볼 수 있다.

상제께서 삼계의 대권(三界·大權)을 수시수의로 행하셨느니 라. 쏟아지는 큰 비를 걷히게 하시려면 종도들에 명하여 화로에 불덩이를 두르게도 하시고 술잔을 두르게도 하시며 말씀으로도 하시고 그 밖에 풍우·상설 - 뇌전을 일으키는 천계대권을 행하 실 때나 그 외에서도 일정한 법이 없었도다.20)

상제가 펼친 삼계대권의 면모를 다각도로 볼 수 있다. 한 예로 큰 비를 멈추는 데는 세 가지 방법이 쓰여서 물과 반대되는 기운인 화로 에 불덩이를 두르게 하거나, 술잔을 두르게 하며, 말씀으로 하였음을 볼 수 있다. 삼계대권의 하나인 천계대권은 풍우(風雨), 상설(霜雪), 뇌전(雷電)과 관계되는데 정해진 법이 없이 수시수의(隨時隨意)로 이 루어져 일정한 법이 없었다고 적혀 있다. 이상에서「공사」편에 등장하 는 삼계대권 관련 구절을 보았다. 이어「권지」편에는 삼계 대권에 대 한 내용이 다음과 같이 등장한다.

나는 서양(西洋) 대법국(大法國) 천계탑(天啓塔)에 내려와서 천하를 대순하다가 삼계의 대권을 갖고 삼계를 개벽하여 선경 을 열고 사멸에 빠진 세계 창생들을 건지려고 너의 동방에 순 회하던 중 이 땅에 머문 것은 곧 참화 중에 묻힌 무명의 약소 민족을 먼저 도와서 만고에 쌓인 원을 풀어주려 하노라.21)

상제께서「내가 삼계 대권을 주재(主宰)하여 선천의 모든 도 수를 뜯어고치고 후천의 새 운수를 열어 선경을 만들리라」22)

20) 공사 1-4.

21) 권지 1-11. 
예문에 상제가 삼계 대권으로 주재(主宰)할 일들이 나타나 있다. 그 것은 3 가지로 삼계의 개벽(開関), 선경(仙境)을 여는 것, 사멸(死滅)에 처한 세계인류를 구하는 것이다. 이는 '삼계 대권을 주재하여 조화로써 천지를 개벽하고 후천선경(後天仙境)을 열어 고해(苦海)에 빠진 중생을 널리 건지려하노라'에서도 거듭해서 볼 수 있다. 아울러 이것은 선천 (先天)의 모든 도수(度數)를 고쳐서 새 운수를 열어 선경을 만드는 것 이 목적임을 알 수 있다. 또 예시(豫示)편에도 삼계대권에 대한 내용이 다음과 같이 적혀있다.

상제께서 하루는 김 형렬에게「삼계대권을 주재하여 조화로 써 천지를 개벽하고 후천선경(後天仙境)을 열어 고해에 빠진 중 생을 널리 건지려하노라.」라고 말씀하시고 또 가라사대「이제 말세를 당하여 앞으로 무극대운(無極大運)이 열리나니 모든 일 에 조심하여 남에게 척을 짓지 말고 죄를 멀리하여 순결한 마 음으로 천지공정(天地公庭)에 참여하라.」고 이르시고 그에게 신 안(神眼)을 열어주어 신명의 회산과 청령(聽令)을 참관케 하셨 도다.23)

상제가 삼계 대권을 소유해서 할 성적(聖蹟)은 예시(豫示) 구절에 '삼계 대권을 주재하여 조화로써 천지를 개벽하고 후천선경(後天仙境) 을 열어 고해(苦海)에 빠진 중생(衆生)을 널리 건지려하노라'고에 잘 나타나 있다. 그리고 이러한 삼계 개벽시대를 맞아 인간들이 할 일은 무극대운(无極大運)24)을 따라 천지공정(天地公庭)에 참여하는 것임을 알 수 있다. 아울러 인간 김형렬에게 신안(神眼)을 열어준 것은 무극 대운과 천지공정이 구천(九天)의 상제를 정점(頂點)으로 하는 신계의 도(道)인 신도(神道)와 깊은 연관성이 있음을 인간 세상에 암시한 것 이 된다.

22) 권지 1-21.

23) 예시 17.

24) 예시 17 , 위의 주 21 참조. 
이상에서『전경』을 통해 개괄적으로 '권(權)'에 대해 보았다. 이어서 상제가 언급한 '지(智)'에 대해서『전경』내용을 통해 포괄적으로 보기 로 한다.

상제께서 전주 이 치안의 집에「고견 원려 왈지(高見遠慮ㅂ 智)」의 글을 써 놓으셨도다.

智者 與天地同 有春夏秋冬之氣 每事 任意用之 謂之智慧勇力

大智 與天地同 有春夏秋冬之氣

其次 與日月同 有弦望晦朔之理

又其次 與鬼神同 有吉风禍福之道25)

예문은 한문(漢文)으로 된 긴 글 가운데 지(智)에 대해서 상제가 언 급한 부분만을 본 것이다. 지(智)에 대한 정의는 “高見遠慮曰智’26)에 핵심적으로 나타나는데 폭 넓은 경지에서 신계와 인간계를 아우르는 차원하에 삼계(三界)에 대해 해박하고 높은 견해(見解)를 갖고 미래의 먼 일까지 생각하는 것이다. 또 지(智)는 “不受恣聰恣明曰智’27)라는 문구에도 요약적으로 잘 드러나 있다. 인간은 스스로 총명함에 빠질 수 있는데 이를 경계하고 겸손한 상태를 가져야 지혜로운 사람이 됨 을 말하고 있다. 스스로 자신을 너무 과대평가하여 총명하다는 자만에 빠져있지 않는 상태의 마음을 견지하는 것이 지(智)임을 보게 된다. 그러기 위해서는 천지의 일과 인간의 만사(萬事)를 알아가는 노력이 요구된다. 천지와 함께 늘 생각하며 상통천문, 하달지리하면서 인간의 일에 중찰인의(中察人義)해 나가는 겸손하고 보편적인 사고를 하는 차 원을 생각할 수 있다. 이러할 때 인간의 지(智)가 천지와 더불어 함께 같을 수 있고 그 차원의 고하(高下)는 천지(天地), 일월(日月), 귀신(鬼 神)으로 나누어 구분됨을 엿볼 수 있다.

25) 제생 43.

26) 고견(高見, 탁월한 의견)과 원려(遠慮, 앞으로 올 일을 헤아리는 깊은 생각)를 지 (智)라고 말한다.

27) 교법 3-47, “不受偏愛偏惡曰仁 不受全是全非日義 不受專强專便日禮 不受恣聰恣明 日智 不受濫物濫欲曰信.” 
즉 천지와 대비되는 지(智)의 차원은 춘하추동(春夏秋冬)의 기(氣) 로, 일월(日月)과 대비되는 지(智)의 차원은 현망회삭(弦望晦朔)의 이 (理)로, 귀신(鬼神)과 대비되는 지(智)의 차원은 길흉화복(吉冈禍福)으 로 차등화 됨을 보이고 있다. 이러한 지(智)는 모든 일을 임의대로 용 사하는 것이며 이를 지혜와 용력으로 상제는 규정하였는데, 위 구절에 서 권(權)과 마찬가지로 지(智)도 천지인 삼계(三界)와 연계되며 인간 이 수행으로 득(得)할 수 있는 차원임을 알 수 있다. 지(智)의 차원은 자연의 운행과 신도의 이치에 맞게 인간의 능력을 신장시켜나가는 노 력에서 얻어지는 것임도 엿볼 수 있다.

또 사덕(四德)이라 일컫는 인의예지는 인간과 신(神)의 도(道)인데 천지의 도인 원형이정과 함께 중요하다.28)『현무경(玄武經)』에도 지 (智)와 관련 지각부가 있어 허령부, 신명부와 함께 관계하며 대응되고 있다. 이러한 관점을 토대로 삼계적 차원의 통합된 개념으로서의 지 (智)에 대한 이해는 다음에서도 볼 수 있다.

또 하루는 공사를 행하시고 오주(五呪)와 글을 쓰시니 이러하 도다. 天文地里 風雲造化 八聞遁甲 六丁六甲 智慧勇力 道通天地報恩 聖師 醫統 慶州龍潭 无極神 大道德奉天命奉神敎大先生前如律令 審行先知後覺 元亨利貞 布敎五十年工夫29)

위의 문구에도 인간의 지혜(智慧)와 용력(勇力)이 나오는데 이는 ‘심행선지후각(審行先知後覺)'이라는 문구의 행(行), 지(知). 각(覺)과 함께 도통(道通)이라는 용어와 대응되어 자세히 살펴 행하여 먼저 아 는 것이 있어야 깨달음이 뒤에 있다는 내용으로 관계된다. '심행(審

28) 교운 2-42, 「운합주(運合呪, “元亨利貞 天地之道 仁義禮智 人神之道.”

29) 예시 88. 
行)'이『중용(中庸)』30)에서 인간의 정성(精誠)에 대해 ‘박학지(博學之) 심문지(審問之) 신사지(愼思之) 명판지(明辦之) 독행(篤行之)'31)하는 것임을 밝힌 글에서 널리 배움(博學之)으로부터 단계를 밟아 궁극적으 로 독실히 행함에 이르는 내용과 대응해서 보면, '심행선지후각'의 각 (覺)에 대해 위의『중용(中庸)』의 글을 함께 생각할 수 있다. 또한 인 간과 다른 격위인 천지(天地)의 보은(報恩)과 무극신(无極神)이라는 내 용은 인간계 차원인 도통(道通), 의통(醫統), 성사(聖師), 대선생(大先 生), 포교오십년공부(布敉五十年工夫)라는 용어와 같이 대비되어 중요 하다. 이는 앞에서 본 “智者 與天地同 有春夏秋冬之氣 每事 任意用之 謂之智慧勇力’과 상관되는 내용으로 특히 위의 ‘天文地里 風雲造化 八 門遁甲 六丁六甲’은 천지(天地)와 연관되며, 인간의 ‘지혜용력(智慧勇 力)'과 맺어져 천지인 삼계에 대한 통합적 지(智)의 차원을 보여준다.

상제께서 류 찬명에게 천문지리 풍운조화 팔문둔갑 육정육갑 지혜용력(天文地理風雲造化 八門遁甲 六丁六甲 智慧勇力)과 회 문산 오선위기혈 무안 승달산 호승례불혈 장성 손륭 선녀직금 혈 태인 배례전 군신봉조혈(回文山五仙圍基穴 務安僧達山胡㑿禮 佛穴 長城巽龍仙女織錦穴 泰仁拜禮田群臣奉詔穴)을 쓰게 하고 불사르셨도다. ${ }^{32)}$

위에서 앞의 예문(예시 88)에 있는 '天文地理風雲造化 八聞遁甲六 丁六甲智慧勇力’이라는 글의 천문(天文)과 지리(地理) 그리고 풍운조화 (風雲造化), 팔문둔갑(八門遁甲), 육정육갑(六丁六甲)과 함께 '지혜용력 (智慧勇力)'이라는 내용은 이번에는 상제가 밝힌 땅(地)의 네 개의 명 당인 사명당(四明堂)33)과 함께 소지(燒紙)되고 있어 그 의미를 심화시

30) 공자(孔子)의 손자인 자사(子思)가 지었다고 함. 교운 1-29, “또 형렬에게 말씀하 시기를「성인의 말은 한 마디도 땅에 떨어지지 아니하나니 고대의 자사(子思)는 성인 이라. 위후(衛侯)에게 말하기를 약차불이 국무유의(若此不已 國無遺矣)라 하였으되 위후가 그 말을 쓰지 않았으므로 위국(衛國)이 나중에 망하였다」 하셨도다.”

31) 『중용(中庸)』.

32) 행록 5-21. 
키고 있음을 알 수 있다. 지혜와 용력이 '천용지용인용통제어심(天用 地用人用統在於心)'34)이라는 말도 있듯이 인존(人尊)의 시대 중찰인의 (中察人義)의 시운(時運)을 맞아 천은 물론이고 지에 대해서도 추기 (樞機)가 되어 깊어짐을 엿볼 수 있다. 이에 이러한 영역과 차원에서 천지인 삼계대권의 권(權)과 마찬가지로 지(智)도 천지인 삼계와 연계 성을 갖고 용사되는 것임을 말해준다. 요컨대 상제의 권능과 지혜는 삼계적 차원과 대응되는 능력으로 초월계와 인간계를 모두 아우르는 절대적 능력임을 엿볼 수 있다. 아울러 인간의 수행도 지혜, 용력을 염두에 두고 우주적 차원에서 이루어져야 됨을 알 수 있다.

\section{III. 상제의 삼계대권으로 본「권지」편 구절 양상}

『전경』의「권지」편 1,2 장의 각 구절 내용을 이어서 표로 요약해보 면 다음과 같다. 먼저「권지」1장 33 개 구절의 내용을 요약해보면 표 와 같다.

〈표 1〉「권지」편 1장(총 33개 구절) 내용요약

\begin{tabular}{|c|l|c|c|}
\hline 절 & \multicolumn{1}{|c|}{ 내용 요약 } & 대권구분 & 시기 \\
\hline 1 & 류서구가 감동한 상제의 예지 & 인계 & \\
\hline 2 & 폭양(曝陽)아래 상제 가는 길에 구름이 가려줌 & 천계 & \\
\hline 3 & 바로 동남풍을 일으킴(제갈량은 칠일칠야 걸림) & 천계 & \\
\hline 4 & 상제가 천지를 돌려 놓음 & 천계, 지계 & \\
\hline
\end{tabular}

33 행록 5-15, “상제께서 백지 한 장의 복판에 사명당(四明堂)이라 쓰시고 치복에게 가라사대「궁을가에 있는 사명당 갱생이란 말은 중 사명당이 아니라 밝을 명자를 쓴 사명당이니 조화는 불법(佛法)에 있으므로 호승예불형(胡䁣禮佛穴)이오. 무병장수(無 病長壽)는 선술(仙術)에 있으니 오선위기혈(五仙圍碁穴)이오. 국태민안(國泰民安)은 군신봉조혈(群臣奉詔穴)이오. 선녀직금혈(仙女織錦穴)로 창생에게 비단 옷을 입히리 니 六月十五日 신농씨(神農氏)의 제사를 지내고 공사를 행하리라."

34) 행록 3-44. 


\begin{tabular}{|c|c|c|c|}
\hline 5 & 보리농사에 수확 없을 것을 예시함 & 천계 & 9월35) \\
\hline 6 & 봄 기후는 순조로웠으나 보리농사 흉년 & 천계 & $\begin{array}{l}\text { 봄-5월 } \\
\text { 5일 }\end{array}$ \\
\hline 7 & 쌀값 폭등에 금년 풍년 되리라, 풍년 구가(謳歌) & 천계 & 7월 \\
\hline 8 & $\begin{array}{l}\text { 아표신(餓莩神)을 천상으로, 기근(飢饉)에 죽는 } \\
\text { 백성 없다함 }\end{array}$ & 천계 & \\
\hline 9 & $\begin{array}{l}\text { 치도령: 여름에 바람이 이슬제거, 겨울에 진흙길이 } \\
\text { 얼고 눈이 녹음 }\end{array}$ & 지계 & \\
\hline 10 & 최운익의 원한을 풀고자 죽을 아들의 약을 지어줌 & 천계 & \\
\hline 11 & 남조선뱃길 도통군자 다시 난다. 대(代)선생 & 인계 & \\
\hline 12 & 치도령: 어재함라산하(御在咸羅山下) & 지계 & $\begin{array}{l}\text { 섣달 } \\
\text { 어느날 }\end{array}$ \\
\hline 13 & 글과 공사로써 도로 상태를 다스리심 & 지계 & \\
\hline 14 & 이직부 집 훈장 상제 시험함(동네 호구 맞춤) & 천계 & \\
\hline 15 & 정남기와 그 아들의 도술 욕심을 거두심 & 인계 & \\
\hline 16 & 우사를 불러 비를 내리심 & 천계 & \\
\hline 17 & 김주보의 처에 여장군 글소지로 제생함 & 인계 & \\
\hline 18 & 윶판에 방탕한 자 깨우침, 일심 교훈 & 인계 & \\
\hline 19 & 박공우 두 마음 경계 & 인계 & \\
\hline 20 & 관운장으로 둔(遁)하심 & 인계 & \\
\hline 21 & 종도들 개벽이 더딘 것을 한탄(恨歎) & 천계, 지계 & \\
\hline 22 & 설후우(雪後雨) 우후상(雨後霜)의 권능을 보임 & 천계 & \\
\hline 23 & 제비봉과 수리개봉에 번개를 침(강감찬 벼락칼) & 천계 & $\begin{array}{l}\text { 어느해 } \\
\text { 여름 }\end{array}$ \\
\hline 24 & 길 상태가 좋아짐에 김보경이 경희(驚喜)함 & 지계 & \\
\hline 25 & 눈이 녹아 길이 좋아짐(甘酒를 나누어 먹음) & 천계 & \\
\hline 26 & 살리는 공부(꿩잡이) & 인계 & \\
\hline 27 & 태양(太陽)을 멈춤(난국에 세태안정 권능 보임) & 천계 & \\
\hline 28 & $\begin{array}{l}\text { 『대학』을 읽으라 했으나 강영학이「황주죽루기」와 } \\
\text { 「엄자능묘기」를 읽자 죽음 예견하고 글을 지어줌 }\end{array}$ & 인계 & $\begin{array}{l}\text { 1904년 } \\
\text { 2월 }\end{array}$ \\
\hline 29 & $\begin{array}{l}\text { 상제의 명 어기고 영학 술서탐독에 시로써 깨닫게 } \\
\text { 했으나 결국 어겨서 죽음 }\end{array}$ & 인계 & \\
\hline 30 & $\begin{array}{l}\text { 장사(葬事) 파의(罷意)하란 예시 어기나 결국 } \\
\text { 토롱(土壟)함(김덕찬 모친상) }\end{array}$ & 지계 & 1904년 \\
\hline 31 & 모악산 용안대에서 식혜를 지어 눈이 녹아 귀가함 & 천계 & \\
\hline 32 & 장독덮개 새끼로 얽어놓으라함(우박 내릴것 예시) & 천계 & \\
\hline 33 & 전주로 박공우를 보내 손병희의 순회를 막음 & 인계 & \\
\hline
\end{tabular}

이어서「권지 편 2장 38 개 구절의 내용을 요약 정리하면 다음과 같다.

35) 연도는 미상. 
〈표 2〉『권지』편 2장(총 38개 구절) 내용요약

\begin{tabular}{|c|c|c|c|}
\hline 절 & 내용 요약 & 대권구분 & 시기 \\
\hline 1 & 박공우 아내 요통(腰痛)에서 제생 & 인계 & \\
\hline 2 & 구름에 가린 별을 보이게 함 & 천계 & \\
\hline 3 & 박공우의 꿈(천상벽악사자) & 인계 & \\
\hline 4 & 상제 순유(巡遊)에 달무리와 햇무리가 나타남 & 천계 & \\
\hline 5 & 일본 포수(砲手)의 뀡잡는 격발을 멈춤 & 인계 & \\
\hline 6 & 몰려오는 큰 비를 멈추심 & 천계 & \\
\hline 7 & 폭우를 멈춤(담배연기, 단오절 학선암) & 천계 & \\
\hline 8 & 김경학의 꿈(천상 상제를 알현) & 인계 & \\
\hline 9 & 구름속 별을 하나씩 나타나게 해서 천문을 봄 & 천계 & \\
\hline 10 & $\begin{array}{l}\text { 청수 동이 주변에는 비 한방울 안 내림(황응종 딸 } \\
\text { 볏집에 청수 올림) }\end{array}$ & 천계 & \\
\hline 11 & 구름을 자유자재로 움직임 & 천계 & \\
\hline 12 & 황응종의 기원(冀願)을 구름 속에서 보심 & 인계 & \\
\hline 13 & 달려오는 세 마리 말을 멈춤 & 인계 & \\
\hline 14 & 폭우에 비 한 방울 맞지 않음(피노리-태인 백암리) & 천계 & \\
\hline 15 & 김경학 집 화재 바람으로 소화(消火)함 & 천계 & 5월 \\
\hline 16 & 큰 비에 김명칠 밭농사 제생(타인 밭은 沙汰) & 천계 & \\
\hline 17 & 뇌성(雷聲)으로 충재(蟲災)를 없앰 & 천계 & 6월 中伏 \\
\hline 18 & 호랑이에 물려간 여인을 구함(좀성 관련) & 천계 & \\
\hline 19 & 가뭄과 충재를 없앰 & 천계 & \\
\hline 20 & 정성원의 세금 관련 잘못을 제생 & 인계 & 1908 \\
\hline 21 & 관운장 초상의 삼각수 & 천계 & 關雲長 \\
\hline 22 & 정심 명함, 방심 통찰 & 인계 & \\
\hline 23 & 태좌법 종도의 움직임을 어느 상황에서든 모두 앎 & 인계 & \\
\hline 24 & $\begin{array}{l}\text { 박공우 순회에 큰 일에 낭패 아니면 남을 좋게 } \\
\text { 말하라 }\end{array}$ & 인계 & \\
\hline 25 & 벽력표 땅에 묻자 번개와 천둥 & 천계 & \\
\hline 26 & $\begin{array}{l}\text { 일주일간 코피 관을 만들라함 감주로 회복, 종도간 } \\
\text { 불화 앎 }\end{array}$ & 인계 & \\
\hline 27 & 한시(漢詩), 양진사 만사(輓詞) & 인계 & \\
\hline 28 & $\begin{array}{l}\text { 과거 구름 속 사람에게 사배한 일을 } \\
\text { 깨우쳐줌(신원일) }\end{array}$ & 인계 & \\
\hline 29 & 이씨 기운을 돋우고 정씨 기운을 꺾는 공사(鄭鑑) & 인계 & \\
\hline 30 & 하늘 구름의 형상(악사 노는 모습)에 헛된 일 말라 & 천계 & \\
\hline 31 & 상제 이미 앎(약방 쌀 사용) & 인계 & 1908.10 \\
\hline 32 & 혼인에 날씨 부조(扶助) & 천계 & \\
\hline 33 & 구름 기둥, 장문(將門) & 천계 & \\
\hline 34 & 차경석이 올 것을 이미 앎 & 인계 & \\
\hline 35 & 가뭄에 우사로 비를 내림, 지성수련 & 천계 & \\
\hline
\end{tabular}




\begin{tabular}{|l|l|l|l|}
\hline 36 & 기후 날씨에 불평 말라 & 천계 & \\
\hline 37 & 진묵 초혼(招魂)하여 선경건설에 참여케 함 & 천계 & \\
\hline 38 & 상제의 사무를 담당함에 김형렬을 경계시킴 & 인계 & \\
\hline
\end{tabular}

다음으로 위의 「권지」편 1,2 장의 구절들을 상제의 삼계대권과 관 련해서 천계, 지계, 인계대권의 세 가지 종류로 분류해서 보고 그 양 상을 논의하기로 한다. 먼저 천계(天界)대권은 하늘과 관련해서 일어 나는 일들에 대해 상제가 용사한 권능을 말한다. 36 )천계대권에 대한 1 장과 2 장 구절들을 보기로 한다. 먼저「권지」편 1장의 천계대권을 표 로 보면 다음과 같다.

〈표 3〉『천계대권』(「권지」편 1장)

\begin{tabular}{|c|c|c|c|}
\hline 절 & 내용 요약 & 대권구분 & 시기 \\
\hline 2 & 폭양(曝陽)아래 상제 가는 길에 구름이 가려줌 & 천계 & \\
\hline 3 & 바로 동남풍을 일으킴(제갈량은 칠일칠야 걸림) & 천계 & \\
\hline 4 & 상제가 천지를 돌려 놓음 & $\begin{array}{l}\text { 천계, } \\
\text { 지계 } 37)\end{array}$ & \\
\hline 5 & 보리농사에 수확 없을 것을 예시함 & 천계 & 9월 \\
\hline 6 & 봄 기후는 순조로웠으나 보리농사 흉년 & 천계 & 봄-5월 5일 \\
\hline 7 & 쌀값 폭등에 금년 풍년 되리라, 풍년 구가(謳歌) & 천계 & 7월 \\
\hline 8 & $\begin{array}{l}\text { 아표신(餓莩神)천상으로 보내 기근에 죽는 백성 } \\
\text { 없다함 }\end{array}$ & 천계 & \\
\hline 10 & 최운익의 원한을 풀고자 죽을 아들의 약을 지어줌 & 천계 & \\
\hline 14 & 이직부 집 훈장 상제 시험함(동네 호구 맞춤) & 천계 & \\
\hline 16 & 우사(雨師)를 불러 비를 내리심 & 천계 & \\
\hline 21 & 종도들 개벽이 더딘 것을 한탄(恨歏) & 천계, 지계 & \\
\hline 22 & 설후우(雪後雨) 우후상(雨後霜)의 권능을 보임 & 천계 & \\
\hline 23 & 제비봉과 수리개봉에 번개를 침(강감찬 벼락칼) & 천계 & 어느해 여름 \\
\hline 25 & 눈이 녹아 길이 좋아짐(甘酒를 나누어 먹음) & 천계 & \\
\hline 27 & 태양(太陽)을 멈춤(난국에 세태안정 권능 보임) & 천계 & \\
\hline 31 & 모악산 용안대에서 식혜를 지어 눈이 녹아 귀가함 & 천계 & \\
\hline 32 & $\begin{array}{l}\text { 장독덮개 새끼로 얽어 놓으라함(우박 내릴 것 } \\
\text { 예시) }\end{array}$ & 천계 & \\
\hline
\end{tabular}

36) 공사 1-4, “상제께서 삼계의 대권(三界 - 大權)을 수시수의로 행하셨느니라. 쏟아지는 큰 비를 걷히게 하시려면 종도들에 명하여 화로에 불덩이를 두르게도 하시고 술잔을 두 르게도 하시며 말씀으로도 하시고 그 밖에 풍우·상설-뇌전을 일으키는 천계대권을 행하실 때나 그 외에서도 일정한 법이 없었도다." 
천계대권은 하늘의 영역과 관련해서 일어나는 일들에 대한 상제의 권능을 말한다. 「권지」편 1장에서 상제의 천계대권은 크게 보아 풍운 조화(風雲造化)나 기후(氣候)와 관련된 것, 신들과 관련된 것 등이다. 풍운(風雲)조화나 기후와 관련된 것은 바로 동남풍을 일으킴, 우사를 불러 비를 내림, 설후우(雪後雨) 우후상(雨後霜)의 이적, 번개를 침, 눈 을 녹임, 태양을 멈춤, 우박올 것을 예시함, 농사관련 기후 등이다. 다 음으로 신들과 관련 된 것은 폭양(曝陽)아래 상제 가는 길에 구름이 가려줌, 최운익 아들의 상태를 알아냄, 동네 호구를 맞춘 것 등이다.

위의 구절들 가운데는 천계만이 아니라 지계대권에도 관련 있는 두 구 절이 보인다. 그것은 상제가 천지(天地)를 돌려 놓음(4절), 종도들 개벽 (開闢)이 더딘 것을 한탄(恨歎)(21절)한 구절로 상제의 대권이 천지에 모 두 관계하고 있음을 보게 된다. 「권지」편 2장의 천계대권을 표로 보면 다음과 같다.

〈표 4〉『천계대권』관련 구절(「권지」편 2장)

\begin{tabular}{|l|l|c|c|}
\hline 절 & \multicolumn{1}{|c|}{ 내용 요약 } & 대권구분 & 시기 \\
\hline 2 & 구름에 가린 별을 보이게 함 & 천계 & \\
\hline 4 & 상제 순유(巡遊)에 달무리와 햇무리가 나타남 & 천계 & \\
\hline 6 & 몰려오는 큰 비를 멈춤 & 천계 & \\
\hline 7 & 폭우를 멈춤(담배연기, 단오절 학선암) & 천계 & \\
\hline 9 & 구름 속 별을 하나씩 나타나게 해서 천문을 봄 & 천계 & \\
\hline \multirow{2}{*}{10} & $\begin{array}{l}\text { 청수 동이 주변에는 비 한방울 안 내림(황응종 딸 } \\
\text { 볍에 청수 올림) }\end{array}$ & 천계 & \\
\hline 11 & 구름을 자유자재로 움직임 & 천계 & \\
\hline 14 & 폭우에 비 한 방울 맞지 않음(피노리-태인 백암리) & 천계 & \\
\hline 15 & 김경학 집 화재 바람으로 소화(消火)함 & 천계 & 5월 \\
\hline 16 & 큰 비에 김명칠 밭농사 제생(타인 밭은 사태) & 천계 & \\
\hline 17 & 뇌성(雷聲)으로 충재(蟲災)를 없앰 & 천계 & 6월 중복 \\
\hline 18 & 호랑이에 물려간 여인을 구함(좀성 관련) & 천계 & \\
\hline 19 & 가뭄과 충재를 없앰 & 천계 & \\
\hline 21 & 관운장 초상의 삼각수 & 천계 & (關雲長) \\
\hline 25 & 벽력표 땅에 묻자 번개와 천둥 & 천계 & \\
\hline
\end{tabular}

37) 천계, 지계가 공통으로 관계함. 


\begin{tabular}{|l|l|l|l|}
\hline 30 & 하늘 구름의 형상(악사 노는 모습)에 헛된 일 말라 & 천계 & \\
\hline 32 & 혼인에 날씨 부조(扶助) & 천계 & \\
\hline 33 & 구름 기둥, 장문(將門) & 천계 & \\
\hline 35 & 가뭄에 우사로 비를 내림, 지성수련 & 천계 & \\
\hline 36 & 기후, 날씨에 불평 말라 & 천계 & \\
\hline 37 & 진묵의 사후 신계(神界)에서의 행적과 해원 & 천계 & (震黙) \\
\hline
\end{tabular}

위의「권지」편 2장에서 상제의 천계대권은 크게 보아 풍운조화(風 雲造化)나 기후(氣候)와 관련된 것, 천문과 관련된 것, 신(神)들과 관 련된 것 등이다. 풍운(風雲)조화나 기후와 관련된 것은 비나 폭우를 멈춤, 청수 동이 주변에는 비 한방울 안 내림, 김경학 집 화재 바람으 로 소화(消火)함, 큰 비에 김명칠 밭농사 제생, 뇌성(雷聲)으로 충재 (蟲災)를 없앰, 가뭄과 충재를 없앰, 벽력표 땅에 묻자 번개와 천둥, 하늘 구름의 형상, 혼인에 날씨 부조(扶助), 가뭄에 우사를 불러 비를 내림 등이다. 다음으로 천문과 관련된 것은 구름에 가린 별을 보이게 함, 구름 속 별을 하나씩 나타나게 해서 천문을 본 것 등이다. 이어서 신들과 관련 된 것은 상제 순유(巡遊)에 달무리와 햇무리가 나타남, 관운장 초상의 삼각수, 구름 모양의 장문(將門), 진묵의 사후(死後) 신 계(神界)에서의 행적과 해원 등으로 볼 수 있을 것이다. 다음으로 지 계(地界)대권은 땅과 관련해서 일어나는 일들에 대한 상제의 권능을 말한다. 지계대권에 대한 구절들은 다음과 같다. 「권지」편 1장의 지계 대권을 표로 보면 다음과 같다.

〈표 5〉『지계대권』관련 구절(「권지」편 1장)38)

\begin{tabular}{|c|l|c|c|}
\hline \multicolumn{1}{|c|}{ 절 } & \multicolumn{1}{|c}{ 냉 요약 } & 대권구분 & 시기 \\
\hline 4 & 상제가 천지를 돌려 놓음 & 천계, 지계 & \\
\hline 9 & $\begin{array}{l}\text { 치도령: 여름에 바람이 이슬제거, 겨울에 진흙길이 } \\
\text { 얼고 눈이 녹음 }\end{array}$ & 지계 & \\
\hline 12 & 치도령: 어재함라산하(御在咸羅山下) & 지계 & $\begin{array}{c}\text { 섣달 } \\
\text { 어느날 }\end{array}$ \\
\hline
\end{tabular}

38)「권지」2장에는 없음. 


\begin{tabular}{|l|l|c|c|}
\hline 13 & 글과 공사로써 도로 상태를 다스리심 & 지계 & \\
\hline 21 & 종도들 개벽이 더딘 것을 한탄(恨歎) & 천계, 지계 & \\
\hline 24 & 길 상태가 ㅈㅗㅗ아짐에 김보경이 경희(驚喜)함 & 지계 & \\
\hline 30 & $\begin{array}{l}\text { 장사(葬事)를 파의(罷意)하란 명 어김 결국 } \\
\text { 토롱(土驡)(김덕찬 모친상) }\end{array}$ & 지계 & 1904 \\
\hline
\end{tabular}

지계(地界)대권은 땅의 영역과 관련해서 일어나는 일들에 대한 상 제의 권능을 말한다. 「권지」편 1장에서 상제의 지계대권은 크게 보아 치도령과 관련된 것, 땅의 상태를 아는 것과 관련 된 구절 등이다.치 도령과 관련된 것이 대부분을 차지한다. 즉 치도령으로 여름에 바람이 이슬제거, 겨울에 진흙길이 얼고 눈이 녹음, 치도령[어재함라산하(御 在咸羅山下)]으로 함라산부터 순창까지의 길의 상태를 다스림, 글과 공사로써 도로 상태를 다스림, 길 상태가 좋아짐에 김보경이 경희(驚 ⿳ㅗㅁ)함 등이다. 땅의 상태를 아는 것과 관련 된 구절은 장사를 지낼 곳 이 의혈(蟻穴)임을 말한 것이다.

세 번째로 인계(人界)대권은 사람과 관련해서 일어나는 일들에 대 한 상제의 권능을 말한다. 인계대권에 대한 1장과 2장 구절들을 보기 로 한다. 먼저「권지」편 1장의 인계대권을 표로 보면 다음과 같다.

〈표 6>인계대권(「권지」편 1장)

\begin{tabular}{|c|l|c|c|}
\hline 절 & \multicolumn{1}{|c|}{ 내용 요약 } & 대권구분 & 시기 \\
\hline 11 & 남조선뱃길 도통군자 다시 난다. 대(代)선생 & 인계 & \\
\hline 15 & 정남기와 그 아들의 도술 욕심을 거둠 & 인계 & \\
\hline 17 & 김주보의 처에 여장군(女將軍)글 소지(燒紙) 제생 & 인계 & \\
\hline 18 & 웃판에 방탕한 자 깨우침, 일심 교훈 & 인계 & \\
\hline 19 & 박공우 두 마음 경계 & 인계 & \\
\hline 20 & 관운장(關雲長)의 형모로 둔(遁)함. & 인계 & \\
\hline 26 & 살리는 공부(꿩잡이) & 인계 & \\
\hline \multirow{2}{*}{28} & $\begin{array}{l}\text { 『대학』을 읽으라 했으나 강영학이「황주죽루기 와 } \\
\text { 엄자능묘기 를 읽자 죽음 예견하고 글을 지어줌 }\end{array}$ & 인계 & $\begin{array}{c}1904 \text { 년 } \\
\text { 2월 }\end{array}$ \\
\hline \multirow{2}{*}{29} & $\begin{array}{l}\text { 상제의 명을 어기고 강영학이 술서를 탐독함에 } \\
\text { 한시(漢詩)로써 깨닫게 했으나 결국 어겨서 죽음 }\end{array}$ & 인계 & \\
\hline 33 & 전주로 박공우를 보내 손병희의 순회를 막음 & 인계 & \\
\hline
\end{tabular}


인계(人界)대권은 인간이 살고 있는 영역과 관련해서 일어나는 일 들에 대한 상제의 권능을 말한다. 「권지」편 1장에서 상제의 인계대권 은 크게 보아 상제 자신의 내력을 말하고 인간사 미래일을 예시(豫示) 한 것, 인간들의 어긋난 욕망을 막음, 사회적 문제의 해결, 인간의 마 음을 통찰함, 형모(形貌)를 바꿈과 관련된 구절 등이다.

상제 자신의 내력에 관한 것은 동학의 최제우(1824 1864)와 관련 해서 대(代)선생임을 밝힌 내용이며39), 인간들의 어긋난 욕망을 막음 은 정남기와 그 아들의 도술 욕심을 거둠, 윶판에 방탕한 자 깨우침, 『대학』을 읽으라 했으나 강영학이「황주죽루기」와「엄자능묘기」를 읽 자 죽음 예견하고 글을 지어줌, 상제의 명(命)을 어기고 강영학이 술 서를 탐독함에 한시(漢詩)로써 깨닫게 했으나 결국 어겨서 죽은 내용 이다. 사회적 문제의 해결에 관한 것은 김주보의 처에 여장군(女將 軍)글 소지(燒紙) 제생, 전주로 박공우를 보내 손병희의 순회를 막은 일 등이다. 인간의 마음을 통찰함과 관련된 것은 박공우가 품은 두 마음 알고 경계한 내용이며, 형모(形貌)를 바꾼 것은 관운장으로 둔 (遁)한 내용이다. 다음으로「권지」편 2장의 인계대권을 표로 보면 다 음과 같다.

〈표 7〉『인계대권』(「권지」편 2장)

\begin{tabular}{|c|l|c|c|}
\hline 절 & \multicolumn{1}{|c|}{ 내용 요약 } & 대권구분 & 시기 \\
\hline 1 & 박공우 아내 요통(腰痛)에서 제생 & 인계 & \\
\hline 3 & 박공우의 꿈(천상벽악사자를 봄) & 인계 & \\
\hline 5 & 일본 포수(砲手)의 꿩잡는 격발을 멈춤 & 인계 & \\
\hline 8 & 김경학의 꿈(천상 상제를 알현) & 인계 & \\
\hline 12 & 황응종의 기원(祈願)을 구름 속에서 봄 & 인계 & \\
\hline 13 & 달려오는 세 마리 말을 멈춤 & 인계 & \\
\hline 20 & 정성원의 세금 관련 잘못을 제생 & 인계 & 1908 \\
\hline 22 & 정심(正心) 명함, 방심(放心) 통찰 & 인계 & \\
\hline
\end{tabular}

39) 권지 1-11, "동학 신자간에 대선생(大先生)이 갱생 하리라고 전하니 이는 대선생 (代先生)이 다시 나리라는 말이니 내가 곧 대선생(代先生)이로다.” 


\begin{tabular}{|l|l|c|c|}
\hline 23 & 태좌법(胎座法) 종도의 움직임 모두 앎 & 인계 & \\
\hline 24 & $\begin{array}{l}\text { 박공우 순회에 큰 일에 낭패 아니면 남을 좋게 } \\
\text { 말하라고 함 }\end{array}$ & 인계 & \\
\hline 26 & $\begin{array}{l}\text { 일주일간 코피 관(棺)을 만들라함 감주(甘酒)로 } \\
\text { 회복, 종도간 불화(不和) 앎 }\end{array}$ & 인계 & \\
\hline 27 & 한시(漢詩), 양진사 만사(輓詞) & 인계 & \\
\hline 28 & $\begin{array}{l}\text { 과거 구름 속 사람에게 사배한 일을 } \\
\text { 깨우쳐줌(신원일) }\end{array}$ & 인계 & \\
\hline 29 & 이씨 기운을 돋우고 정씨 기운을 꺾는 공사(奠鑑) & 인계 & \\
\hline 31 & 상제 이미 앎(약방 쌀 사용) & 인계 & 1908.10 \\
\hline 34 & 차경석이 올 것을 이미 앎 & 인계 & \\
\hline 38 & 상제의 사무를 담당함에 김형렬을 경계시킴 & 인계 & \\
\hline
\end{tabular}

「권지」편 2장에서 상제의 인계대권은 제생, 인간의 꿈이나 기원을 앎, 인간 및 동물(말)의 동작을 제어함 40$)$, 인간의 마음을 통찰함, 시 공을 초월 인간의 행동을 통찰함, 사회적 문제의 해결과 관련된 구절 등이다. 제생에 관한 것은 박공우 아내 요통(腰痛)에서 제생, 정성원의 세금 관련 잘못을 제생한 내용이다. 인간의 꿈이나 기원을 아는 것은 박공우의 꿈(천상벽악사자를 봄), 김경학의 꿈(천상 상제를 알현), 과 거 구름 속 사람에게 사배한 일을 깨우쳐줌(신원일), 황응종의 기원 (祈願)을 구름 속에서 본 일 등이다. 인간 및 동물의 동작을 제어함은 일본 포수(砲手)의 뀡 잡는 격발을 멈춤, 달려오는 세 마리 말을 멈춘 것이다. 인간의 마음을 통찰함은 정심(正心)을 명함과 방심(放心)을 알 고 있는 것과 상제의 사무를 담당함에 김형렬의 마음을 알고 경계시 킨 내용 등이다. 시공을 초월 인간의 행동을 통찰함은 태좌법(胎座法) 시 종도의 움직임을 모두 앎, 박공우 순회에 큰 일에 남을 좋게 말하 라고 함, 종도간 불화(不和)를 앎, 약방 쌀 사용을 앎, 차경석이 올 것

40) 행록 4-34, "또 어느날 낙양의 들 근방을 지나실 때 황소 두 마리가 싸우는 것을 보시고 가까이 다가가서 뿔을 두 손으로 하나 씩 잡고 소 귀에 무슨 말씀을 이르시니 소들이 흩어져 가는도다."; 행록2-15, "상제께서 대원사에서의 공부를 마치고 옷을 갈아입고 방에서 나오시니 대원사 골짜기에 각색의 새와 각종의 짐승이 갑자기 모여 들어 반기면서 무엇을 애원하는 듯 하니라. 이것을 보시고 상제께서 가라사대「너희 무리들도 후천 해원을 구하려함인가 하시니 금수들이 알아들은 듯이 머리를 숙이는 도다. 상제께서 「알았으니 물러들 가있거라」고 타이르시니 수 많은 금수들이 그 이르 심을 좇는도다." 
을 이미 아는 것 등이다. 사회적 문제의 해결과 관련된 것은 이씨 기 운을 돋우고 정씨 기운을 꺾는 공사[鄭鑑]를 본 일이다.

한편, 「권지」편 두 구절에 대해 내용상으로 보아 삼계에 대해 상제 가 용사한 대권의 양상을 중심으로 1 장, 2 장을 표로 보면 다음과 같다.

<표 8〉「권지」구절의 삼계대권의 분포 양상

\begin{tabular}{|l|c|c|c|c|c|}
\hline \multicolumn{1}{|c|}{ 권지 } & 천계대권 & 지계대권 & 인계대권 & $\begin{array}{c}\text { 천·지계 } \\
\text { 대권41) }\end{array}$ & 비고 \\
\hline 1장(33절) & 15 개 & 5 개 & 11개 & 2개 & 연도별42) \\
\hline 2장(38절) & 21 개 & 0개 & 17개 & 0 & 연도별43) \\
\hline 총 71절 & 36 개 & 5개 & 28개 & 2개 & \\
\hline
\end{tabular}

구절수로 보았을 때「권지」편은 1장이 33절, 2장이 38절로 총 71절 이다. 장별로 삼계(三界)의 각 계별 대권의 개수를 보면 1 장이 천계대 권이 15 개, 지계대권이 5 개, 인계대권이 11 개이다. 2 장에서는 천계대 권이 21 개, 지계대권이 0 개, 인계대권이 17 개이다. 천계대권은 1 장이, 지계대권도 1 장이, 인계대권은 2장이 많은 수를 싣고 있다. 「권지」편 전체로 보면 천계대권의 내용이 가장 많고, 이어서 인계대권, 지계대권 의 순서로 되어 있다. 이상 위에서 「권지」편 1, 2장의 구절들에 대해 천계, 지계, 인계대권으로 나누어 그 세부적 내용들의 양상을 살펴 보 았다. 다음 장에서는 「권지」편 외『전경』 다른 편에 나타나는 권지적 성격의 구절들을 삼계대권에 따라 보고 두 개의 장으로 되어 있는 「권 지」편 장(章)의 특성을 다른 편의 장과 비교해서 보기로 한다.

41) 구절에 개벽(천지개벽)의 더딤을 한탄, 천지를 돌려놓음 내용의 구절임.

42) 28절이 1904년 2월이고 30절이 1904년 임, 28절 앞의 구절은 연도를 추정할 수 없이 월만 나오는 구절이 있음. 31절부터는 연월일이 없음.

43) 20절이 1908년이고 그 앞 구절은 연도를 추정할 수 없음. 이하 31절이 1908년 10 월임. 32 절부터는 연월일이 없음. 


\section{IV.「권지」편 외『전경』다른 편44)에서의 삼계대권의 양상과「권지」편 장(章)의 분류 고찰}

\section{1.『전경』다른 편에 나타난 삼계대권의 양상}

이장에서는 「권지」편 구절을 중심으로 다른 편에 나타난 권지적 성격의 내용을 살펴보기로 한다. 앞 장에서도 보았지만『전경』의 7 개 편 가운데「권지」편보다「공사」편에 상제의 삼계대권과 관련된 구 절45)이 먼저 나타남을 볼 수 있는데, 이는 각종 공사들에 상제의 권 지가 근간(根幹)이 되어 천지공사가 이루어져 선천 상극(相克) 세상이 후천 상생(相生) 세상으로 되기 때문이다. 나아가『전경』 각 편들은 공사의 양상을 보여주는 대표성을 지닌 제목이기에 그 편 내(內)에 상제의 권지적 성격의 구절이 존재한다. 즉 상제의 권지는 『전경』의 「행록」,「공사」,「교운」,「교법」,「제생」,「예시」편 등과 관련해서도 발현(發顯)되는 것이므로 좀 더 상제의 권지를 총괄적으로 이해하기 위해, 「권지」편 1, 2장에서 찾아본 삼계대권을 토대로 다른 편에 나타 나는 권지적 성격의 구절들을 탐색해 볼 수 있다. 그리고 천계, 지계, 인계 대권 모두가 다양하게 나타나는 편은「행록」,「공사」,「교운」편 1장들46)이라 할 수 있으므로 이 편(編)들에서 권지적 성격의 구절들

44) 이글에서는 지면상 대표적으로「공사 편 1장만을 고찰하였음을 밝혀둔다.

45) 공사 1-1, “시속에 말하는 개벽장은 삼계의 대권을 주재하여 비겁에 쌓인 신명과 창 생을 건지는 개벽장(開䦕長)을 말함이니라."; 공사 1-2, “상제께서 이듬해 미월에 김 형렬의 집에서 삼계를 개벽하는 공사를 행하셨도다. 나는 삼계의 대권을 주재하여 선 천의 도수를 뜯어고치고 후천의 무궁한 선운을 열어 낙원을 세우리라」 하시고「너는 나를 믿고 힘을 다하라」고 분부하셨도다."; 공사 1-4, "상제께서 삼계의 대권(三界. 大權)을 수시수의로 행하셨느니라. 쏟아지는 큰 비를 걷히게 하시려면 종도들에 명하 여 화로에 불덩이를 두르게도 하시고 술잔을 두르게도 하시며 말씀으로도 하시고 그 밖에 풍우·상설-뇌전을 일으키는 천계대권을 행하실 때나 그외에서도 일정한 법이 없었도다."

46) 교법은 대부분이 인계에서의 인간의 윤리도덕적 법에 관한 것이므로 인계대권과 
을 찾아 더 많은 자료들을 봄으로써 상제의 권지에 대한 이해의 폭을 넓힐 수 있을 것이다.

먼저 앞 장에서 논의한 「권지」1장과 2장을 종합해서 상제의 삼 계대권을 보면47) 상제의 천계대권은 하늘의 영역과 관련해서 일어 나는 일들에 대한 상제의 권능을 말하며, 상제의 천계대권은 크게 보아 1. 풍운조화(風雲造化)，2. 기후(氣候)，3. 천문(天文)，4. 신(神) 들과 관련된 것 등이다. 상제의 지계(地界)대권은 땅의 영역과 관련 해서 일어나는 일들에 대한 상제의 권능을 말하며, 크게 보아 1. 치 도령, 2. 땅의 상태(風水地理)와 관련된 구절 등이다. 상제의 인계대 권은 크게 보아 1. 상제 자신을 밝힌 것, 2. 상제의 둔(遁), 3. 미래 인간사를 예시(豫示)한 것, 4. 인간들의 어긋난 욕망을 막은 것, 5. 인간의 마음을 통찰함, 6. 인간의 꿈이나 기원(祈願)을 앎, 7. 인간의 동작을 제어함, 8. 시공을 초월 인간의 행동을 통찰, 9. 제생(濟生), 10. 사회적 문제의 해결과 관련된 구절 등으로 대별된다. 삼계대권 가운데 인계대권의 양상이 다양함을 볼 수 있다. 이를 토대로 지면 상 『전경』 전체 내용을 다 살펴보지는 못하고 삼계대권을 용사한 내용이 잘 나타난「공사」편 1장과 관련해서 삼계대권의 양상을 보기 로 한다. ${ }^{48)}$

「공사」편 1장에도 공사와 관련해서 삼계대권 관련 내용이 등장한다. 이는 삼계대권을 용사하여 천지공사가 이루어졌음을 보여준다.

깊이 관련되고, 제생은 인간의 병에 대해 상제가 용사한 인계대권이 중심이며, 예시 도 대부분이 인계에서의 미래 일을 예시한 것이므로 인계대권으로 되어 있다.

47) 이에 대한 분류는 천, 지, 인으로 확연히 구분되는 구절도 있으나 신(神)과 관련된 구절이 있거나 한 계(界)에 권능을 보여 다른 계(界)에 결과가 나타나는 경우도 볼 수 있다. 이런 경우 신(神)과 관련된 「권지 구절은 대부분 천계대권으로 보았으며, 한 계(界)에 권능을 보여 다른 계(界)에 결과가 나타나는 경우에는 그 목적하는 바 를 중심으로 대권을 분류했음을 밝혀둔다.

48) 이글에서는 지면상「공사」1장에 대해서만 보기로 한다. 
〈표 9>「공사」편 1장에 나타난 삼계대권의 양상

\begin{tabular}{|c|c|c|c|}
\hline 절 & 내용 요약 & 대권구분 & 神관련 내용 \\
\hline 5 & 명부 & 천계 & \\
\hline 7 & 명부공사 & 천계 & \\
\hline 8 & 태양 천하종기 파 & 천계 & \\
\hline 11 & 묵은 하늘 & 천계 & \\
\hline 12 & 서양 물리침 & 천계 & \\
\hline 13 & 동양 수호 & 천계 & \\
\hline 14 & 진묵초혼 & 천계 & 진묵 \\
\hline 15 & 진묵초혼 & 천계 & 진묵 \\
\hline 16 & 호소신 & 천계 & 호소신 \\
\hline 17 & 천자부해상 & 인계 & \\
\hline 18 & 천자부해상, 번개 치는 곳에 안경을 던짐 & 천계 & \\
\hline 19 & 남대문에 글을 붙임 & 인계 & \\
\hline 20 & 오의관 병 제생 & 인계 & \\
\hline 21 & 김갑칠 제생, 오의관 처 제생 & 인계 & \\
\hline 22 & 사십년도 십년(벽력표를 묻음) & 인계 & \\
\hline 23 & 화둔(火遁)을 씀 & 천계 & \\
\hline 24 & 비를 내려 최익현 의병 거두고 민족 활로를 염 & 천계 & \\
\hline 25 & 촌양반과 아전 화해(천하 해원) & 인계 & \\
\hline 26 & 상등인의 고기(개고기) & $\begin{array}{l}\text { 천계, } \\
\text { 인계 }\end{array}$ & 망량 \\
\hline 27 & 농암(籠㜟) 기운 & 지계 & \\
\hline 28 & 일곱고을 용지불갈 & 천계 & \\
\hline 29 & 중천신 해원 & 천계 & 중천신 \\
\hline 30 & 종도 평가 & 인계 & \\
\hline 31 & 앞으로 오는 좋은 세상 & 인계 & \\
\hline 32 & 남녀 평등 & 인계 & \\
\hline 33 & 마음으로 천문지리 & 인계 & \\
\hline 34 & 만고명장(전봉준, 백의한사로 천하를 움직임) & 인계 & \\
\hline 35 & 서양 문명이기 사용 & 인계 & \\
\hline 36 & 병겁과 의통 & 인계 & \\
\hline
\end{tabular}

위의 표에서 천계(天界)대권은 천계 명부(冥府)와 관련해서 주장자 (主張者)를 다시 정하는 것과 하늘에 대한 것(묵은 하늘) 그리고 천하 의 종기를 파(破)(태양에 햇무리)하는 공사, 서양세력 퇴치, 동양을 수 호, 화둔(火遁), 일곱 고을의 풍년공사 등이다. 신(神)과 관련된 것으로 는 신명공사, 진묵(震黑)대사에 대한 초혼(招魂)과 호소신(好笑神) 및 
중천신(中天神) 해원, 비를 내려 의병에 참여한 생민(生民)을 제생한 것 등이다. 지계대권은 농암(籠澉)이라는 장소에 대해 밝힌 일이며, 다 수를 차지하는 인계대권은 천자부해상(天子浮海上) 공사, 치병(治病)을 통한 제생, 사회적 상황과 관련해서 천하해원, 남녀평등, 서양 문명이 기의 사용, 병겁과 의통(醫通) 등이다. 또 종도에 대한 평가 및 인간 마음을 통한 풍운조화의 시험도 있다. 또한 두 개의 대권이 같이 나타 나는 것으로는 상등인(上等人)의 고기와 망량신(魅魎神)에 관한 것이다.

\section{2. 「권지」편 장(章)의 분류 고찰}

이번에는 「권지」편이 두 개의 장(章)으로 나누어져 있는 것에 주목 해서 1 장과 2 장으로의 분류의 기준을 찾아보기로 한다. 여기에서는 다 른 면보다 우선 권능과 지혜라는 같은 내용의 두 개의 장이 하나의 장 으로 되지 않고 장이 분류된 것이 어떠한 방식인가에 주목해서 보기로 한다. 이는 두 개장 이상으로 되어 있는 『전경』의 편들에 대한 구성의 원리를 살펴보는 일을 토대로 편마다의 장의 분류 기준을 찾아보는 작 업을 선행(先行)으로 이루어지는 「권지」편 1장과 2장에 대한 분류기준 에 대한 탐색이라 할 수 있다. 두 개 장으로 되어 있는 「권지」편을 살 펴보며 1장과 2장으로 나누어진 분류기준이 어떠한가를 보는 것은 편 (編), 장(章), 절(節)로 이루어진 『전경』의 주축적 구성에서『전경』을

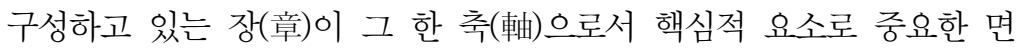
모가 되기도 하기 때문이다.

이를 위해 먼저 두 개 이상의 장으로 되어 있는 『전경』의 각 편의 장을 살펴보기로 한다. 『전경』의 각 편에서「권지」편을 포함해서 2개 이상의 장으로 된 편은 「행록」,「공사」,「교운」,「교법」편 등 총 5개 장이며, 1 개 장으로 된 편은「제생」과「예시」이다. 2 개 이상의 장으로 된 편과 한 개의 장으로 된 편은 『전경』전체에서 순서대로 되어 있음 을 볼 수 있다. 즉 그 순서가 '행록 $\rightarrow$ 공사 $\rightarrow$ 교운 $\rightarrow$ 교법 $\rightarrow$ 권지 $\rightarrow$ 제 
생 $\rightarrow$ 예시'인데 앞 5 편은 여러 개 장이고, 뒤 2 개 장은 한 개의 장이 다. 여기에서 2개 장 이상으로 되어 있는 각 편의 장수(章數)를 보면, 총 7 개 편에서 행록은 5 개 장, 공사는 3 개 장, 교운은 2 개 장, 교법은 3 개 장, 권지는 2 개 장이다, 이중 교운은 1 장이 구천상제에 관한 기록 이고 2장은 조성옥황상제에 대한 기록으로 되어 있어 구천상제에 대한 기록만으로 여러 개의 장인 편들과 다르다. 여기에서 2 개 장 이상으로 되어 있는 각 편의 구성에서의 면모를 표로 보면 다음과 같다.

〈표 10〉2개 장 이상인「행록」,「공사」「「교운」,「교법」구절의 구성

\begin{tabular}{|c|c|c|c|c|}
\hline & 행록(총 5장) & 공사(총 3장) & 교운(총 2장) & 교법(총 3장) \\
\hline 1장 & 1871년 - & 1901년 - & $\begin{array}{l}\text { 구천상제. 1902년 } \\
\text { 여름-1909.1.1 }\end{array}$ & \\
\hline 2장 & 1897년 - & 1907년 3월 - & $\begin{array}{l}\text { 조성옥황상제의 } \\
\text { 생애(1895-1958) }\end{array}$ & \\
\hline 3장 & 1904년 - & 1908년 봄 - & & \\
\hline 4장 & 1908년 초(6절) - & & & \\
\hline 5장 & 1909년 1월 2일 - & & & \\
\hline $\begin{array}{l}\text { 분장 } \\
\text { 의 } \\
\text { 특징 }\end{array}$ & $\begin{array}{l}\text { 생애의 연도별 } \\
\text { 기록, }\end{array}$ & $\begin{array}{l}\text { 공사의 연도별 } \\
\text { 기록, }\end{array}$ & $\begin{array}{l}\text { 1장에서는 } \\
\text { ㄱㅊㅓㅓ상제, } \\
\text { 2장에서는 천부적 } \\
\text { 종통계승을 한 } \\
\text { 도주 조정산에 } \\
\text { 대한 기록, 각 장이 } \\
\text { 연도별 기록. 교운 } \\
\text { 1장에 玄武經 }\end{array}$ & $\begin{array}{l}\text { 교법의 연도에 } \\
\text { 구애받지 않은 } \\
\text { 기록 }\end{array}$ \\
\hline 비고 & $\begin{array}{l}\text { 강성, 강세지, } \\
\text { 5장의 끝 구절에 } \\
\text { 병세문(장문의 } \\
\text { 한문) }\end{array}$ & $\begin{array}{l}\text { 3장의 끝 구절에 } \\
\text { 장문의 한문 }\end{array}$ & $\begin{array}{l}\text { 교운 1장의 끝 } \\
\text { 구절에 현무경, } \\
\text { 교운 2장엔 } \\
\text { 장문의 한문 없음 }\end{array}$ & $\begin{array}{l}\text { 3장 끝 구절에 } \\
\text { 장문의 한문 }\end{array}$ \\
\hline
\end{tabular}

이상의 표를 보면 2 개 이상의 장으로 되어 있는 각 편의 장 별 구 분의 특징은 대별해서 다음과 같다. 행록 편은 장의 구분이 연도별로 되어 있다. 각 장의 구절 수의 배치는 1장이 38절, 2장이 24절, 3장 이 66절, 4장이 57절, 5장이 38절로 총 구절 수는 223절이다.

「공사」편도 연도별로 되어 있다. 각 장의 구절 수의 배치는 1 장이 36절, 2장이 28절, 3장이 42절로 총 구절 수는 106절이다. 교운은 1 
장이 구천상제에 대한 기록이고, 2장이 조성 옥황상제에 대한 기록이 다. 교운 1,2 장 모두 연도별로 되어 있다. 각 장의 구절 수의 배치는 1장이 66절, 2장이 67절로 총 구절 수는 133절이다. 교법은 연도별 로 되어 있지 않다. 각 장의 구절 수의 배치는 1장이 68절, 2장이 58 절, 3 장이 47 절로 총 구절 수의 배치는 173 절이다. 이상 2 개 장 이상 으로 된 편을 보았다. 다음으로 1 개 장으로 되어 있는「제생」,「예시」 편을 표로 보면 다음과 같다.

<표 11>1개 장인「제생」과「예시」구절의 구성

\begin{tabular}{|l|l|l|}
\hline & \multicolumn{1}{|c|}{ 제생 1장(44절) } & \multicolumn{1}{c|}{ 예시 1장(89절) } \\
\hline 특징 & $\begin{array}{l}\text { 44개 구절 중 연도가 있는 구절은 두 } \\
\text { 비고 }\end{array}$ & \begin{tabular}{l} 
장문의 한문(43도별 굴성 \\
\hline
\end{tabular} \\
\hline
\end{tabular}

제생과 예시는 다른 편과 다르게 1 개 장인데 이 두 편은 『전경』 총 7 개 편 가운데 순서가 끝 2 개의 편이다. 그리고「제생」과「예시」편의 구절 수를 보았을 때 제생은 44 절로 구절이 적어서 1 개 장이 될 수 있 다(행록 편 2장이 최소구절로 24절임).「권지」가 총 71 절로 2개 장으 로 되어 있는데, 반면 예시는 89 개의 구절로 「권지」 1,2 장의 총 구절 수보다 더 많아서 2 개 장이 될 수도 있는데, 「예시」가 1 개 장인 것을 보면 『전경』의 각 편의 장이 5 개(행록) 또는 3 개(공사, 교법) 혹은 2 개 (교운, 권지)로 나누어지는 것이 구절 수와는 상관없이 끝 두 개의 편 을 1장으로 하였음을 유추해 볼 수 있다. 이상의 방식으로『전경』각 편과 비교해보면「권지」편 구절의 구성도 형식상 연도별의 추보식(推步 ⿹弋工)으로 되어 있다. 이상에서 여러 개의 장으로 되어 있는 『전경』의 5 개 편에서의 장의 분류에 대한 기준은 교법을 제외하고 공통점은 연도 별로 이루어졌다는 것이다. 내용상으로 보아도 이외 장의 분류에 대한 규칙성을 특별히 찾을 수 없다. 이러한 면은 이글에서 고찰하고 있는 「권지」편도 예외가 아님을 보게 된다. 다음 장에서는「권지」편 구절들 을 대순전경 6판에서 찾아 두 문헌의 구절들을 비교해보기로 한다. 


\section{V. 「권지」편 구절의『대순전경』6판 구절과의 비교}

\section{1.「권지」편 1장 구절의 비교 및 차이점}

『전경』, 「권지」편 1장 구절들에 대해 그 변이(變移)를『대순전경』6 판(1965)과 비교해서49)보기로 한다.50)

2절:(2-125) '상제께서 가시는 여름의 폭양길'이 '더울 때에 출입 하시면'으로 되어 있다. '양산과 같이 태양을 가려'가 '일산(日众)과 같 이 태양을 가려'로 용어상 차이가 있다. '그늘이 지는 도다’는 ‘볕이 쪼이지 아니하니라'로 강하게 표현되었다. 3절:(2-14) '동남풍을 불게 하였다'가 '동남풍을 불렸다'는 것으로 되어 있다. 7절:(2-16) 몇 년도 인지 알 수 없이 '이해 7월에'로 되어 있으나 '계묘 7월에'로 계묘년 으로 년도가 확연히 나타난다. '신축년부터 내가 일체의 천지공사를 맡았으니 금년에는 농작물이 잘 되게 하리라'가 '신축년 이후로는 연 사(年事)를 내가 맡았으니 금년 농사를 잘 되게 하여 민록(民祿)을 넉 넉케 하리라'로 되어 있다. '이해에 비가 적절히 내리고 햇볕이 쪼이더 니 들판에서는 온통 풍년을 구가하니라'가 ‘크게 우레와 번개를 일으키 시니 이로부터 충재(蟲災)가 그치고 농사가 크게 풍등(豐登)하니라’로 되어 있어 상제의 권능 용사가 다르게 기록되어 있다. 9절:(2-11, 12) 9절의 첫 번째 문장의 '치도령을 내리시니라'가 6판 11절에서는 치도 령을 써서 불사른 것으로 되어 있고, 이어서 12절에 하운동이 산중으 로 길이 좁고 나무숲들이 우거져 얽혀 있다는 부분이 나온다. 이어서 여름과 겨울의 상황이 기록되어 있는데 6판 11절에는 겨울에 진 길을 얼어붙게 하신 뒤 마른 신발로 다니신 것으로 되어 있으나 9절에는

49) 이는 6판이 대순전경의 최종판으로 가장 풍부하게 많은 구절을 담고 있기 때문이다.

50) 이는 「권지」편 1장 구절을 중심으로 변이를 살펴보는 것이다. 20 개 구절 정도를 살펴 본 후 두 문헌의 차이점의 양상을 표의 비고(備考)에서 요약해서 보기로 한다. 
길이 얼어붙기도 하고 눈이 녹기도 하였다고만 되어 있어 다르다. 또 6판 12절의 이슬이 많고 장마시에 시내를 이루나 상제의 신발은 항상 깨끗하여 마을 사람들이 모두 이상히 여겼다는 내용이 없다. 11 절:(3-22) '상제께서 어느 날 경석을 데리고 농암(籠岩)을 떠나 정읍 으로 가는 도중에 원평 주막에 들러 지나가는 행인을 불러 술을 사 서 권하고 「이 길이 남조선 뱃길이라. 짐을 많이 실어야 떠나리라」 고 말씀하시고 다시 길을 재촉하여 三十리 되는 곳에 이르러「대진 (大陣)은 일행 三十리라」하시고 고부 송월리(松月里) 최(崔)씨의 재실 에 거주하는 박공우(朴公又)의 집에 유숙하셨도다’라는 내용이 11절에 는 앞 부분에 더 있다. '나는 서양(西洋) 대법국(大法國) 천계탑(天啓 塔)에 내려와서 천하를 대순하다가'가 '서천서역대법국천계탑 천하(天 下)대순(大巡)이라'로 되어 있다. '삼계의 대권을 갖고 삼계를 개벽하 여 선경을 열고 사멸에 빠진 세계 창생들을 건지려고 너의 동방에 순 회하던 중 이 땅에 머문 것은 곧 참화 중에 묻힌 무명의 약소 민족을 먼저 도와서 만고에 쌓인 원을 풀어주려 하노라. 나를 좇는 자는 영원 한 복록을 얻어 불로불사하며 영원한 선경의 낙을 누릴 것이니 이것 이 참동학이니라’가 ‘동학주에「시천주조화정」이라 하였으니 내 일을 이름이라'가 앞에 더 있고, '내가 천지를 개벽하고 조화정부를 열어 인간과 하늘의 혼란을 바로 잡으려 하여 삼계를 둘러 살피다가 너의 동토에 그쳐 잔피(舟疲)에 빠진 민중을 먼저 건지려함이니 나를 믿는 자는 무궁한 행복을 얻어 선경의 낙을 누리리니'로 되어 있어 '삼계의 대권을 갖고'라는 구절이 없고 조선에 대해서도 '참화 중에 묻힌 무명 의 약소 민족을 먼저 도와서 만고에 쌓인 원을 풀어주려 하노라'로 되 어 국가해원의 의미가 11절에는 명료히 나타나고 있다. 3장 22절에는 뒷 부분에 '예로부터 계룡산의 정씨왕국과 가야산의 조씨왕국과 칠산 의 범씨왕국을 일러오나 이 뒤로는 모든 말이 영자(影子)를 나타내지 못하리라 그러므로 정씨를 찾아 운수를 구하려 하지 말지어다'가 추가 되어 있다. 12절:(2-45) '섣달 어느날 종도들과 함께 동곡으로 가시는 
데 길이 진훍으로 심히 험하거늘'이 '섣달에' 및 '함열로부터 구릿골 로 가실 때 길이 심히 질어서 길 걷기가 어려운지라로 되어 있다. 이어서 12 절에는 '치도령을 내리시니 질던 길이 곧 굳어지니라. 마른 짚신을 신고 동곡에 가실 수 있었도다'로 되어 있으나 6판에는 치도 령글인 “「어재함라산하이어우전주동곡(御在咸羅山下移御于全州銅谷)」 이라 써서 불사시니'의 기록이 있은 후 '질던 길이 곧 굳어지니라. 마 른 짚신을 신고 동곡에 가실 수 있었도다'로 마무리 되어 있다. 이에 대해 12절은 치도령 한문 글귀도 '그 당시 쓰신 치도령은 「어제함라 산하(御在咸羅山下)」의 여섯 글자인 바 상제께서 이것을 불사르셨도 다'로 되어 있어 '이어우전주동곡(御在咸羅山下移御于全州銅谷)'이 없 이 간단하고 후술(後述)로 되어 있다. 14절:(1-31) '그 후에 상제께 서 김제 반월리(金堤半月里) 김준희(金駿熙)의 집에 계셨을 때 전주 이동면 전룡리(全州伊東面田龍里)에 사는 이 직부의 부친이 상제를 초빙하는 도다'로 자세히 설명되어 있으나 6판에는 '치안이 천사의 신기하심을 흠모하여 자기 집으로 모셔온 것'으로 되어 있다. '그 집 훈장이 상제의 재주를 시험하고자 하는 것을 미리 아셨도다'로 되어 있으나 6판에는 '치안의 아들 직부가 이장이라 마침 그 마을 인구를 긴급히 조사할 일이 있다 하여 상제가 수를 놓은 것'으로 되어 있다. 또 6판 끝에는 '직부가 비로소 놀라 천사의 신기하심을 감복하니라' 가 추가 되어 있다. 15절:(2-19, 20) 6판에는 맨 앞에 '천사의 아우 영학이 항상 도술통하기를 상제께 발원했다'는 내용이 더 있다. 이에 상제가 그 방법을 가르쳐준 것으로 되어 있다. 6판에는 '부채의 아름 다움을 탐냈다'고 되어 있다. 아울러 정남기와 그의 아들이 상제의 도력을 빼앗고자 하운동에 이른 것도 15절에는 '상제가 우묵골로부터 하운동에 오시는 길'이라고 되어 있고 또 '남기의 아들이 상제께서 오신다는 말을 듣고 겁을 먹고 도망가거늘 남기가 붙들고 와서 상제 께 배알하니 상제께서 그의 속셈을 꿰뜷고'라고 남기 아들의 행동을 자세히 기록하고 있다. 17절:(2-86) '백남신의 친족인 백용안(白龍安) 
이 관부로부터 술도매의 경영권을 얻으므로써 전주 부중에 있는 수 백개의 작은 주막이 폐지하게 되니라'가 '용안이 술도가 면허를 얻고 전주 부중에 있는 수백 술집에 술 빚는 것을 금하니’로 되어 있다. 김주보 처의 말도 17 절에는 '통곡하는 울분의 소리를 듣고 가엾게 여 겨'로 역동적으로 기록되어 있다. '그 아내가 갑자기 기운을 얻고 밖 으로 뛰어나가 소리를 지르는도다. 순식간에 주모들이 모여 백용안의 집을 급습하니 형세가 험악하게 되니라’는 기록이 6판에는 간단히 '주보의 아내가 신기(神氣)를 얻어서 부중을 돌며 호령하여 잠시에 수백 주모를 모아 거느리고 용안의 집을 엄습(掩襲)하여 형세가 불온 하거늘’로 적혀 신기를 얻어 모아서 거느리고 간 것으로 되어 있어 서술이 17 절과 다르다. 끝 부분에 '이에 당황한 나머지 그는 주모들 앞에서 사과하고 도매 주점을 폐지할 것을 약속하니 주모들이 흩어졌 도다. 용안은 곧 주점을 그만 두었도다라는 긴 서술이 6판에는 간단 히 '용안이 크게 놀라 군중에게 사과하고 술도가를 중지하니라'로 되 어 있다. 19절:(3-36) 19절에는 공우가 가만히 일을 보고 온 것으로 되어 있으나 36절에는 비밀히 일진회 사무소에 들어간 것으로 되어 있다. 또 36 절에는 '한 어깨에 두 짐을 지면 더수기가 찟어지나니'가 더 추가되어 있다.

〈표 12〉「권지」편 1장 구절(1 19절) 내용요약 및 6판과의 비교

\begin{tabular}{|c|c|c|}
\hline 절 & 「권지」편 1장 구절의 6판과의 비교 내용 & 비고 \\
\hline 2 & 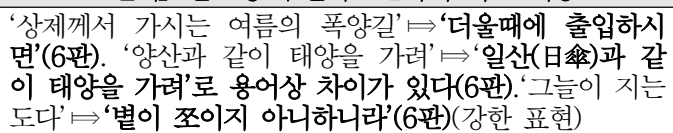 & $\begin{array}{l}\text { 내용차이, 용어차이, } \\
\text { 내용표현강조(6판) }\end{array}$ \\
\hline 3 & ‘동남풍을 불게 하였다’ ’동남풍을 불렸다’(6판). & 용어차이 \\
\hline 8 & 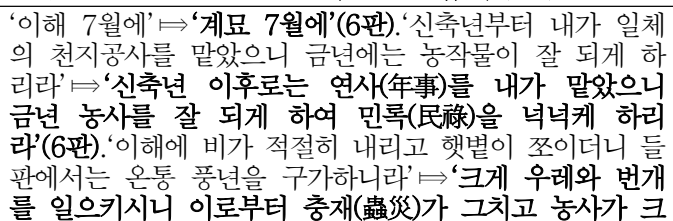 & $\begin{array}{l}\text { 연도있음(6판)내용서 } \\
\text { 술차이(권능에 대해) }\end{array}$ \\
\hline
\end{tabular}




\begin{tabular}{|c|c|c|}
\hline & 게 풍등(豐登)하니라'(6판)(권능 용사기록 차이) & \\
\hline 9 & $\begin{array}{l}9 \text { 절의 첫 번째 문장의 ‘치도령을 내리시니라' } \Longleftrightarrow 6 \text { 판 } 11 \\
\text { 절에서는 치도령을 써서 불사른 것으로 되어 있고, 이어 } \\
\text { 서 } 12 \text { 절 내용으로 하운동이 산중으로 길이 좁고 나무술 } \\
\text { 들이 우거져 얽혀 있다는 부분이 나온다. 이어서 여름과 } \\
\text { 겨울의 상황이 기록됨. 9절에는 길이 얼어붙기도 하고 } \\
\text { 눈이 녹기도 하였닥겨울에 진 길을 얼어붙게 하신 뒤 } \\
\text { 마른 신발로 다니신 것으로 되어 있음(6판). } 9 \text { 절에는 } 6 \\
\text { 판 } 12 \text { 절의 이슬이 많고 장마시에 시내를 이루나 상제의 } \\
\text { 신발은 항상 깨끗하여 마을 사람들이 모두 이상히 여겼 } \\
\text { 다는 내용이 없다. }\end{array}$ & $\begin{array}{l}\text { 내용차이 } \\
\text { 내용추가 }\end{array}$ \\
\hline 11 & 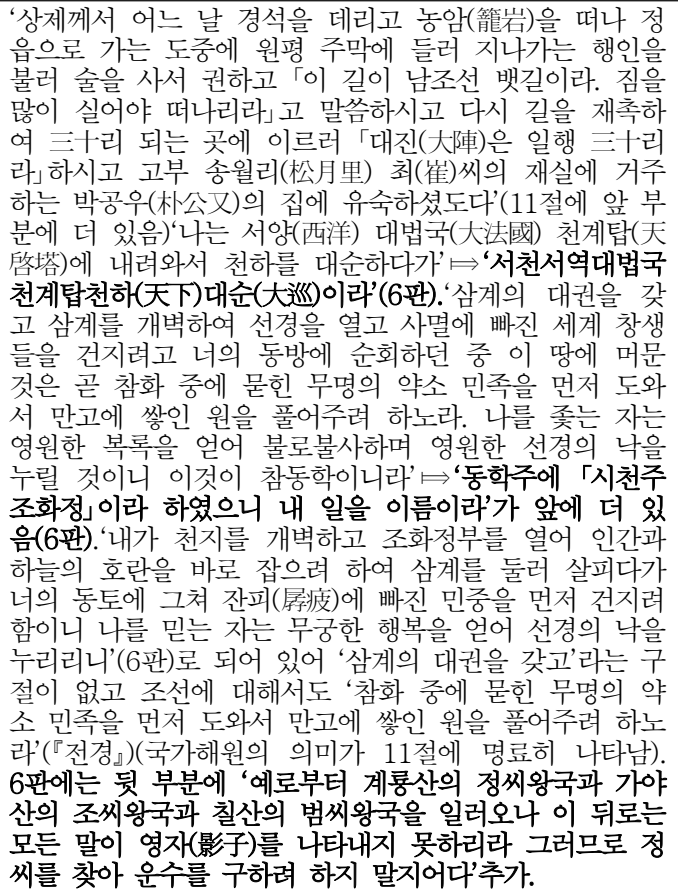 & $\begin{array}{l}\text { 내용추가(『전경』, } \\
\text { 앞부분, 6판 문미), } \\
\text { 내용차이, } \\
\text { 내용추가(6판)51) } \\
\text { 의미 강조(『전경』, } \\
\text { 국가해원) }\end{array}$ \\
\hline 12 & 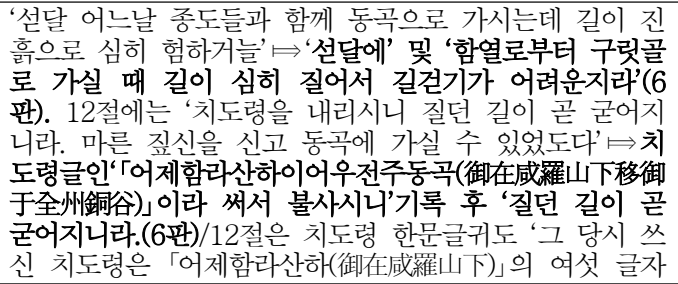 & $\begin{array}{l}\text { 내용서술의 } \\
\text { 차이(비교적 같은 } \\
\text { 내용서술에 차이, } \\
\text { 6판) }\end{array}$ \\
\hline
\end{tabular}




\begin{tabular}{|c|c|c|}
\hline & 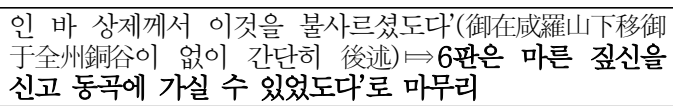 & \\
\hline 14 & 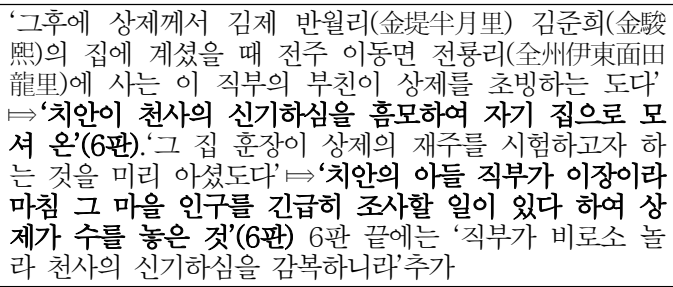 & $\begin{array}{l}\text { 내용 } \\
\text { 상세서술(『전경』, } \\
\text { 앞부분)내용 } \\
\text { 차이(상제 시험 한 } \\
\text { 이가 다름), } \\
\text { 내용추가(6판, 문미) }\end{array}$ \\
\hline 15 & $\begin{array}{l}\text { 6판에는 맨 앞에 '천사의 아우 영학이 항상 도술통하기 } \\
\text { 를 상제께 발원했다'는 내용이 더 있음. 이에 상제가 그 } \\
\text { 방법을 가르쳐줌. 6판에는'부채의 아름다움을 탐냈다'내 } \\
\text { 용 추가. 아울러 정남기와 그의 아들이 상제의 도력을 } \\
\text { 빼앗고자 하운동에 이른 것도 } 15 \text { 절에는 '상제가 우묵골 } \\
\text { 로부터 하운동에 오시는 길'이라고 되어 있고 또 '남기의 } \\
\text { 아들이 상제께서 오신다는 말을 듣고 겁을 먹고 도망가 } \\
\text { 거늘 남기가 붙들고 와서 상제께 배알하니 상제께서 그 } \\
\text { 의 속셈을 꿰뚫고'(남기 아들행동 상세기록) }\end{array}$ & $\begin{array}{l}\text { 내용추가(6판), } \\
\text { 내용차이, } \\
\text { 내용상세기술(『전경』) }\end{array}$ \\
\hline 17 & 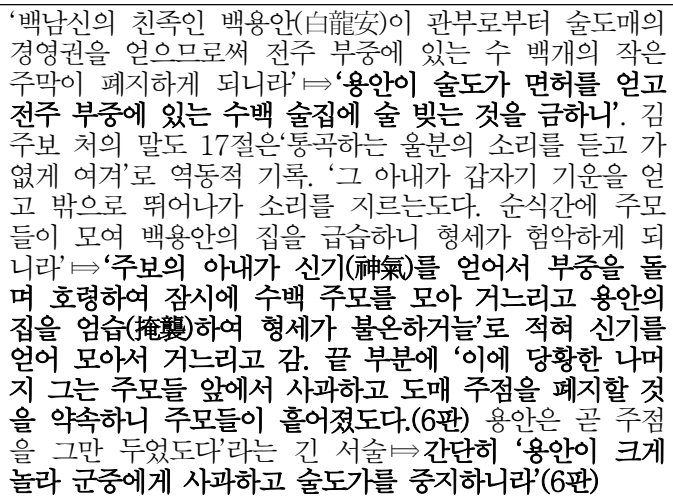 & $\begin{array}{l}\text { 내용차이, 서술차이 } \\
\text { ( } 6 \text { 판이 간략, 『전경』 } \\
\text { 역동적이고 긴 서술) }\end{array}$ \\
\hline 19 & $\begin{array}{l}19 \text { 절에는 공우가 가만히 일을 보고 온 것비미밀히 일진 } \\
\text { 회 사무소에 들어간 것(6판)또 6판 36절에는 '한 어깨에 } \\
\text { 두 짐을 지면 더수기가 찣어지나니'가 더 추가. }\end{array}$ & $\begin{array}{l}\text { 내용차이 } \\
\text { 내용추가 }\end{array}$ \\
\hline
\end{tabular}

20절:(4-90) 20절에는 '내 얼굴이 관운장과 같으냐'는 상제의 물음 에 공우가 '놀라며 대답하지 못하고 주저하거늘'로 되어 있으나 6판에 는 '어떻게 대답하는 것이 좋을지 몰라서 알지 못한다'고 대답한 것으 
로 되어 있다. 이후 20절에서는 세 번을 물은 후 공우가 정신을 차려 서 '관운장과 흡사하나이다'로 대답한 것으로 되어 있으나 6판에는 정 신을 차려 답했다는 내용이 아니라 평상적으로 답한 것으로 되어 있 어 20절의 기록이 상제의 관운장으로의 둔(遁)에 공우가 더 긴장하고 놀란 것으로 기록되어 있다. 24절:(2-55) 6판 55절에는 공중(公衆)의 교통(交通)을 편리케 하기 위해 길을 얼어붙게 청(請)한 것으로 되어 있고 이에 상제가 허락하여 술을 마시니 그날 밤 길이 얼어서 세말 (歲末)까지 녹지 않은 것으로 되어 있다. 이 내용이 24절에는 상제가 웃고 아무 말이 없었으며 다음 날 원일이 아침길에 길이 얼어서 놀 라고 기뻐한 것으로 되어 있어 다르다. 27절:(2-56) 27절에는 겨울 어느 날로 되어 있다. 앞산 봉우리로 되어 있으나 6 판에는 앞 제비 산 봉우리로 나온다. '「이제 난국에 제하여 태양을 멈추는 권능을 갖 지 못하고 어찌 세태를 안정시킬 뜻을 품으랴. 내 이제 시험하여 보 리라」’가 ‘이러한 난국에 정세(靖世)에 뜻을 품은 자는 능히 일행(日 行)을 멈추게 하는 권능을 가지지 못하면 불가할지니 시험하여 보리 라’로 되어, 영탄형(詠歎型)의 문장이 평서문으로서 '정세에 뜻을 품은 자'가 주어로 기록되어 있다. 28절:(2-26) 갑진년 2월이 6판에는 연 도가 없이 2월에로 되어 있다. '굴치에 계실 때'가 '밤재에 계실 때'로 되어 다르다. '그는 황주 죽루기(黃州竹樓記)와 엄자능 묘기(嚴子陵廟 記)를 읽으니라. 상제께서「대(竹)는 죽을 때 바꾸어 가는 말이요. 묘 기(廟記)는 제문이므로'가 6판에는 없다. 즉 영학이 멀지 않아 죽게 되는 세부적인 상제의 평이 없다. 영학이 죽게 된다는 표현도 못보게 되리라로 나온다. 28절에는 한시만을 전한 것으로 되어 있으나 6판에 는 한시 뒤에 '영학으로 하여금 살펴 깨닫게 하시되 영학이 종시(終 붓) 살펴깨닫지 못하니라'는 내용이 추가되어 강조하고 있다. 29 절:(2-27) 29절에는 도술을 배우려는 영학에게 대학을 읽으라 했으나 상제의 명(命)을 어기며, 술서를 공부해서 28절의 내용처럼 시를 보내 어 깨닫게 했으나 영학이 죽었다고 나온다. 또 상제가 내림하여 영학 의 입에 엄지손가락을 대고 유언한 후 엄지 손가락을 떼니 영학이 죽 
었다고 나온다. 6판에는 이러한 내용이 없이 영학이 병들어 위독했는 데 상제가 듣고 김갑칠과 밤재에 갈 때 한 주막에서 한 사람이 허리 가 굽어서 엎디어 기어 다녀 그 사연을 듣고 그 곱사등이의 허리를 펴준 것으로 되어있다. 또 열 닷 낭을 가져오라했으나 그가 가진 돈이 없어 널로 갚아 그 널로 영학이 죽어 장사지낸 것으로 되어 두 판본 의 내용이 완전 다르다. 31절:(2-35) 섣달 어느 날로 되어 있으나 6 판에는 섣달이 없다. '일기가 화창(和暢)하여 쌓인 눈도'가 '일기가 화 난(和暖)케 되어 장설(丈雪)로 쌓인 눈이'로 되어 용어상 다르다. 32 절:(2-18) '음식을 드시고'가 6판에는 '술을 잡수시고'로 되어 다르다. '우박이 오리라'는 구절 뒤에 6판에는 '편편파쇄(片片破碎)하리라'는 구절이 더 있다. 33절:(4-33) '천도교 손병희(孫秉熙)가 호남 일대를 순회하고자 전주에 내려와서 머물었도다'가 '상제가 원평을 지나 신암 (新庵) 주막에 이르사 손병희가 전주에 왔는데'로 되어 있다. '상제께서 공우에게 「네가 전주에 가서 손병희를 돌려보내고 오라. 그는 사설로 교도를 유혹하여 그 피폐가 커지니 그의 순회가 옳지 않다」고 분부를 내리셨도다'가 6판에는 공우는 등장하지 않고 상제의 말52)에 황응종이 몽둥이를 들며 여쭈어 자신이 쫓아가서 손병희를 쫓아내겠다고 한 것 으로 적혀 있다. 이어 응종에게 상제가 '네가 진실로 쾌남자(快男子)로 다' 하고 '저희들은 다 구암(久庵)이요 이곳은 신암(新庵)이니 곧 도안 (都安)의 집이니라 하시니라’고 기록되어 있다. '공우가 복명하였으되 이튿날 거기에 대해서는 아무런 말씀이 계시지 않으므로 이상히 여겼 느니라. 며칠 후에 손병희는 예정한 순회를 중지하고 경성으로 되돌아 갔도다'가 6판에는 '손병희가 호남지방을 순회하려다가 뜻밖에 예정을 변경하여 돌아가니라'로 되어 있다.

52 『대순전경』 6판에는'손병희가 전주에 왔는데 서울에 교당을 짓는다 빙자하고 그 부하의 어린 아해들 옷고름에 채운 돈까지 떼어다가 큰 집과 작은 집을 거느리고 행락하며 온 부하들을 망친다하니 그 무능함을 가히 알지라 만일 재능이 있으면 천 하 집이 모두 저의 집이 될지니 집을 지어 무엇하리요 이제 호남 각지를 돌면 그 부하들은 다 망하리라 이제 누구든지 몽둥이를 들어 그 머리를 치며 네 재능이 무 엇이건대 부하들을 그다지 망치느냐고 꾸짖으면 대답하지 못하고 돌아가리라'(4장 33절)고 적혀 있다. 
〈표 13〉「권지」편 1장 구절(20 33절) 내용요약 및 6판과의 비교

\begin{tabular}{|c|c|c|}
\hline 절 & 「권지」 편 1 장 구절의 6판과의 비교 내용 & 비고 \\
\hline 20 & 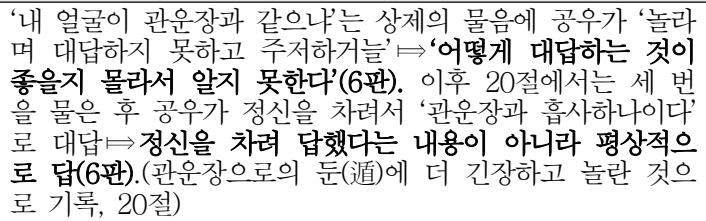 & $\begin{array}{l}\text { 서술의 차이 } \\
\text { (전경』, 종도의 } \\
\text { 긴장감 강조) }\end{array}$ \\
\hline 24 & $\begin{array}{l}\text { 24절에는 상제가 웃고 아무 말이 없었으며 다음 날 원일이 } \\
\text { 아침 길에 길이 얼어서 놀라고 기버함음판에는 공중(公 } \\
\text { 衆)의 교통(交通)을 편리케 하기 위해 길을 얼어붙게 청(請) } \\
\text { 한 것으로 되어 있고 이에 상제가 허락하여 술을 마시니 } \\
\text { 그날 밤 길이 얼어서 세말(歲末)까지 녹지 않음. }\end{array}$ & 내용차이 \\
\hline 27 & 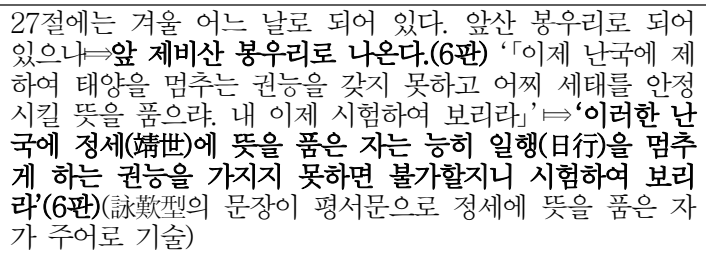 & $\begin{array}{l}\text { 시기있음(『전경』), } \\
\text { 상세기록 } \\
\text { (『전경』, 제비산), } \\
\text { 서술차이(『전경』, } \\
\text { 영탄형으로 } \\
\text { 의미강조, 행위의 } \\
\text { 주체강조) }\end{array}$ \\
\hline 28 & 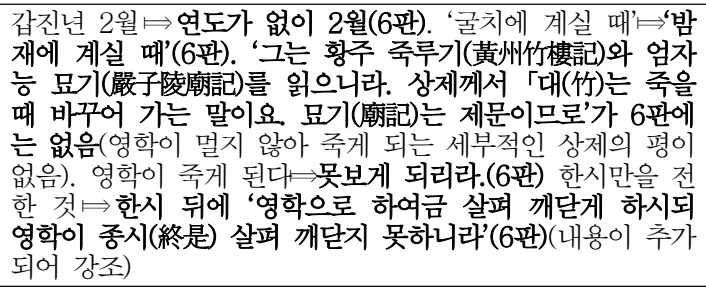 & $\begin{array}{l}\text { 연도있음(『전경』), } \\
\text { 창소차이, } \\
\text { 내용추가(『전경』, } \\
\text { 고문진보의 한시). } \\
\text { 서술차이, } \\
\text { 내용추가(6판, } \\
\text { 문미, 의미강조) }\end{array}$ \\
\hline 29 & $\begin{array}{l}29 \text { 절에는 도술을 배우려는 영학에게 대학을 읽으라 했으나 } \\
\text { 상제의 명(쇼)을 어기며, 술서를 공부에 28절의 내용처럼 } \\
\text { 시를 보내어 깨닫게 했으나 영학이 죽었다고 나온다. 또 상 } \\
\text { 제가 내림하여 영학의 입에 엄지손가락을 대고 유언한 후 } \\
\text { 엄지 손가락을 떼니 영학이 죽었다고 나온다. 6판에는 이러 } \\
\text { 한 내용이 없이 영학이 병들어 위독했는데 상제가 듣고 김 } \\
\text { 갑칠과 밤재에 갈 때 한 주막에서 한 사람이 허리가 굽어 } \\
\text { 서 엎디어 기어 다녀그 사연을 듣고 그 곱사등이의 허리 } \\
\text { 를 펴주고 열 닷 냥을 가져오라했으나 그가 가진 돈이 없 } \\
\text { 어 널로 갚아 그 널로 영학이 죽어 장사지낸 것으로 되어 } \\
\text { 두 판본의 내용이 완전 다르다. }\end{array}$ & 새로운 내용(6판) \\
\hline 31 & $\begin{array}{l}\text { 섣달 어느날 } \Longleftrightarrow \text { 달이 없음(6판)'일기가 화창(和暢)하여 쌓인 } \\
\text { 눈일기가 화난(和暖)케 되어 장설(丈雪)로 쌓인 눈'(6 } \\
\text { 판)(용어 다름) }\end{array}$ & $\begin{array}{l}\text { 시기있음(『전경』), } \\
\text { 내용서술차이 }\end{array}$ \\
\hline 32 & $\begin{array}{l}\text { ‘음식을 드시고’ } \Longrightarrow \text { ‘술을 잡수시고’(6판),'우박이 오리라’구절 } \\
\text { 뒤에 6판에는 '편편파쇄(片片破碎)하리라'는 구절 더 있음. }\end{array}$ & $\begin{array}{l}\text { 내용차이(음식 } \rightarrow \\
\text { 술), 내용추가 } 6 \text { 판, } \\
\text { 강조) }\end{array}$ \\
\hline
\end{tabular}




\begin{tabular}{|c|c|c|}
\hline 33 & 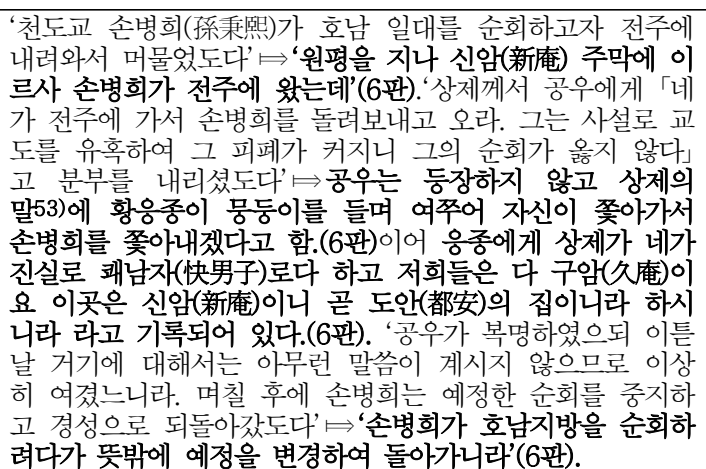 & $\begin{array}{l}\text { 내용서술차이(6판, } \\
\text { 1.상제 이동 경로, } \\
\text { 2.장문의 손병희 } \\
\text { 활동내용추가 } 54 \text { ), } \\
\text { 3.등장하는 } \\
\text { 종도의 } \\
\text { 차이<문공신과 } \\
\text { 황응종>. } \\
\text { 『전경』은 문미 에 } \\
\text { 상세 기록 추가) }\end{array}$ \\
\hline
\end{tabular}

\section{2. 「권지」편 2장 구절의 비교 및 차이점}

1절:(8-34) 6판에는 공우의 아내가 겨울에 물을 긷다가 빙판에 엎 어져서 중상을 당하여 청수를 떠놓고 빈 것으로 되어 있어 다르다. 1 절에는 이어서 공우가 큰 돌을 들다가 다쳐 제생한 내용이 연속으로 기록되어 6판과 다르다. 2절:(4-96) 두 문헌의 내용이 서술의 전개나 용어상 같으나 ‘헛기침을 하시니’가 ‘입으로 한번 부시니’로 되어 있 다. 4절:(2-78) '달무리', '햇무리'가 '달머리', ‘햇머리'로 되어 있다. 5 절:(2-57) ‘기러기 떼에게 총을 겨누고'가 '기러기 떼가 많이 앉은 곳 을 향하여 총을 겨누고’로 되어 있으며, ‘차마 보지 못하겠노라’가 ‘군 자(君子) 차마 보지 못할 일이라'로 적혀 있다. '왼발로 땅을 한번 구 르시고 그 자리에 서시니라' 다음에 6판에는 '그 총이 쏘아지지 아니 한지라 사냥꾼이 이유를 알지 못하고 총을 검사하고 헤메는 차에'라는 격발(擊發) 이전 상황에 대한 부연된 기술이 더 적혀 있다. 6절:6판 2 장 59절과 같다. 7절:(2-62) 동리 사람들이 상제를 배알하고 소풍하 기를 상제에게 청한 것으로 되어 있으나 6 판에는 종도들과 마을 사람

53) 주 52 참조.

54) 6 판에는 손병희에 대한 비판적 기록이 장문으로 상세히 기록되어 있고 손병희의 행동을 막기 위한 황응종의 대처방식도 강력하게 기술됨. 
들이 상제를 모시고 간 것으로 기록되어 다르다. 또 상제가 김자현을 데리고 가다가 폭우를 만난 것으로 적혀 있으나 6판에는 전체적으로 김자현이 나타나지 않고 있어 많은 차이가 있다. '사람들이 달음박질 하여 비를 피하려고 하나 상제께서 자현을 불러「천천히 갈지어다」고 이르시고'라는 부분이 6판에는 없다. '노방에 앉으셔서 담배를 피우시 고 몰려오는 구름 쪽을 향하여 담배 연기를 품으셨도다'는 내용도 6 판에는 '담뱃대로 몰려 오는 비를 향하여 한번 두른 것'으로 되어 있 다. '자리를 뜨시며 천천히 걸어 학선암에 이르시니 곧 비가 억세게 내리기 시작하였도다도 6판에는 비가 다른 곳으로 몰려가더니 학선 암에 이른 뒤에 비가 몰려 오는 것으로 기록되어 세부적으로 그 내용 이 다르다. 12절:(8-51) 12절에 손을 모으고 있었다는 내용이 6판에 는 응종이 손을 비비고 있었다는 표현으로 기록되어 있다. 13 절:(2-60) 말을 탄 세 사람을 보고 발로 땅바닥을 구르고 다리 머리 에서 걸음을 멈춘 것으로 되어 있으나 6판에는 먼저 발을 구른 후 이 어서 말 탄 세 사람이 나타난 것으로만 되어 있다. '달려오던 말이 갑 자기 움직이지 않으니'가 ‘다리 건너편에 이르러 말 발굽이 땅에 붙어 서 옮기지 못하므로'로 적혀 있다. 16절:(2-92) ‘김명칠이 백암리 사 는 종도로 거름을 주고 담배를 가꾸었는데 하루는 번개가 치고 비가 세차게 퍼붓느니라'로 되어 있는데 6판에는 거름을 하고 붓을 하였더 니 문득 소나기가 온 것으로 되어 있다. '비탈진 산전에 거름을 준 후 라 억수가 내리면 거름은 물론 밭두둑까지 사태가 나는 것이 상례이 기에’라는 설명을 한 후 ‘명칠이 가슴을 치며「내 농사는 이것뿐인데 이 억수로 버리게 되었으니 어찌 살랴」고 울음을 터뜨렸도다'라고 기 록되어 있으나 6판에는 김명칠이 직접화법으로 '가슴을 치며 울어 가 로대 내 농사는 담배 농사뿐인데 거름하고 붓한 뒤에 이렇게 소나기 가 퍼부으니 사태가 밀어내려서 다 버리게 되리라'한 것으로 적혀 있 다. 비가 개인 것도 16 절에는 상제가 '내가 수재를 면케 하리니 근심 걱정하지 말지어다라고 하자 내리던 비가 개는 것으로 되어 있으나 6 판에는 단순히 '비가 개인 뒤에’라고 기술하여 상제의 권능에 대한 설 
명이 없다. 또한 16 절에는 구절의 말미에 '명칠은 새삼스럽게 상제를 공경하는 마음을 게을리 하지 않았느니라'는 내용이 있어 종도가 감동 한 마음이 잘 드러나 있다. 17절:(2-66) 6월 중복날 접지리에서 경석 을 비롯한 여러 종도들을 만나 일화가 이루어진 것으로 기록되어 있 으나 6판에는 시간과 장소가 없고 종도들에게 말한 것으로만 되어 있 다. '뇌성', ‘우뢰 소리', '번개', '천둥' 등으로 나오나 6판에는 일관되 게 '번개'로만 기록되어 있다. 우레 소리가 없어 짚을 준비한 것에 대 해서도 '종도에게 마른 짚 한 개만 가져오게 하시고 그것을 무명지에 맞추어 잘라서 화롯불에 꽂고 다 태우시니라'고 되어 있으나 6판에는 '마른 짚을 끊어서 화로에 꽂아 사르시니'라고만 간단히 기록되어, 종 도가 가져왔다거나 상제의 무명지에 맞추어 잘랐다는 자세한 내용이 없다. '사방에서 번개가 번쩍이고 천둥이 쳤도다'도 6판에는 '사방에서 번개가 번쩍이더라'로 되어 있다. 18절:(2-75) '한여름에 정읍의 버들 리에서 젊은 여자가 범에게 물려 갔는데 이도삼이 정읍 수통목에 계 시는 상제를 찾아 뵈옵고 그 일을 아뢰니라'고 기록되어 있다. 이 부 분이 6판에는 하루는 정읍 수통목에 유숙할 때 공우가 시측(侍側)할 때 이도삼이 와서 20세쯤 된 여자가 범에게 물려갔다는 말을 고한 것 으로 되어 있어 한여름이라는 계절이 없고 공우가 시측했다는 내용이 없다. 또 젊은 여자를 20세쯤 된 여자로 구체적으로 기술하고 있는 점이 다르다. 아울러'그 여자가 몸에 조그만한 상처만을 입고 살아 돌 아왔느니라'는 부분도 의복은 파열되었으나 몸의 상해는 크지않다고 적고 있다. 18절의 '좀성'은 6판에서 '충성(蟲星)'으로 되어 있다. 20 절:(2-90) 6판에는 '정성원이 가난하여 살수가 없어 상제에게 가난 면할 길을 가르쳐 달라하자 상제가 웃으며, 금년 마을 세금을 상납하 지 말고 쓰라하고 뒷일은 상제가 끌러주리라하자 정성원이 너무 심한 말씀이라 하고 국세를 받아 쓰고 어찌 생명을 보전하리이까하고 물러 간 내용'이 구절의 앞 부분에 상세히 기록되어 있다. 관청의 독촉이 '무신년'으로 되어 있으나 6판에는 '기유년 봄'으로 되어 시기가 완전 히 다르다. 상제가 '너무 염려하지 말라. 장차 무사하게 되리라'고 무 
마(掹摩)한 것으로 되어 있으나 6판에는 무사하게 하여주리라하니 모 든 사람이 다 믿지 않았다는 내용으로 되어 있다. '과연 무기 세금이 면제 되었도다’도 6판에는 '성원의 일이 끌리니라’가 추가되어 정성원 에게 아무런 해가 없었음을 강조하고 있다.

〈표 14〉「권지」편 2장 구절(1 20절) 내용요약 및 6판과의 비교

\begin{tabular}{|c|c|c|}
\hline 절 & 「권지」 편 1장 구절의 6판과의 비교 내용 & 비고 \\
\hline 1 & $\begin{array}{l}\text { 6판에는 공우의 아내가 겨울에 물을 긷다가 빙판에 엎어져 } \\
\text { 서 중상을 당하여 청수를 떠놓고 빈 것으로 되어 있어 다르 } \\
\text { 다. } 1 \text { 절에는 이어서 공우가 큰 돌을 들다가 다쳐 제생한 내 } \\
\text { 용이 연속으로 기록되어 } 6 \text { 판과 다르다. }\end{array}$ & $\begin{array}{l}\text { 내용의 차이. } \\
\text { 다른 줄거리 } \\
\text { 추가(『전경』) }\end{array}$ \\
\hline 2 & ‘헛기침을 하시니’ ‘’입으로 한번 부시니’(6판) & 내용차이 \\
\hline 4 & ‘달무리'‘햇무리’ $\risingdotseq$ ‘달머리'‘햇머리’(6판) & 내용차이 \\
\hline 5 & 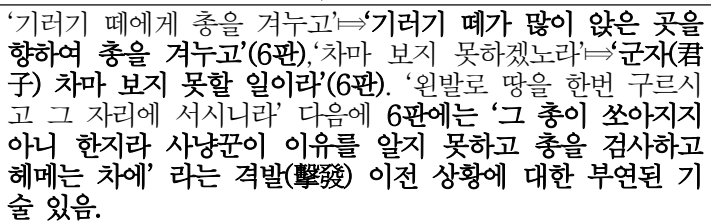 & $\begin{array}{l}\text { 내용차이 } \\
\text { 내용추가부연 } \\
\text { (6판) }\end{array}$ \\
\hline 7 & 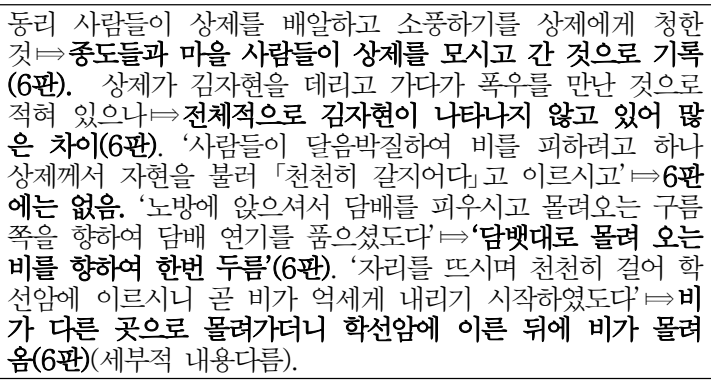 & $\begin{array}{l}\text { 내용 차이. } \\
\text { 내용이 한쪽 } \\
\text { 문헌에만 } \\
\text { 있음(『전경』) }\end{array}$ \\
\hline 12 & 12절에 손을 모으고 있었다 $\Leftrightarrow$ 응종이 손을 비비고 있었다(6판) & 내용차이 \\
\hline 13 & $\begin{array}{l}\text { 말을 탄 세 사람을 보고 발로 땅바닥을 구르고 다리 머리에 } \\
\text { 서 걸음을 멈춤먼저 발을 구른 후 이어서 말 탄 세 사람 } \\
\text { 이 나타남.(6판)/‘달려오던 말이 갑자기 움직이지 않으닐 } \\
\text { '다리 건너편에 이르러 말 발굽이 땅에 붙어서 옮기지 못하 } \\
\text { 므로'(6판) }\end{array}$ & 내용차이. \\
\hline 16 & $\begin{array}{l}\text { '김명칠이 백암리 사는 종도로 거름을 주고 담배를 가꾸었는 } \\
\text { 데 하루는 번개가 치고 비가 세차게 퍼붓느니라' } \Longleftrightarrow \text { 거름을 } \\
\text { 하고 붓을 하였더니 문득 소나기가 내림(6판).'비탈진 산전 } \\
\text { 에 거름을 준 후라 억수가 내리면 거름은 물론 밭두둑까지 } \\
\text { 사태가 나는 것이 상례이기에'라는 설명을 한 후 '명칠이 가 } \\
\text { 슴을 치며 「내 농사는 이것 뿐인데 이 억수로 버리게 되었 }\end{array}$ & $\begin{array}{l}\text { 내용서술의 } \\
\text { 차이(6판은 } \\
\text { 단순기술) }\end{array}$ \\
\hline
\end{tabular}




\begin{tabular}{|c|c|c|}
\hline & 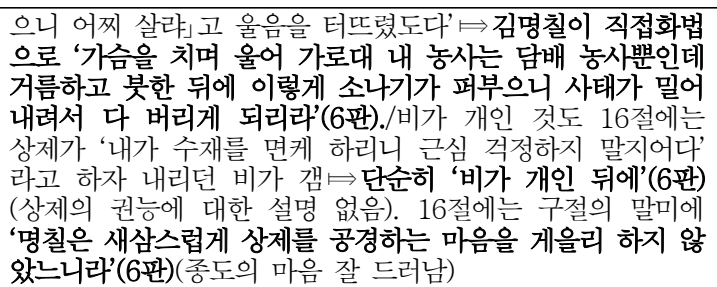 & \\
\hline 17 & 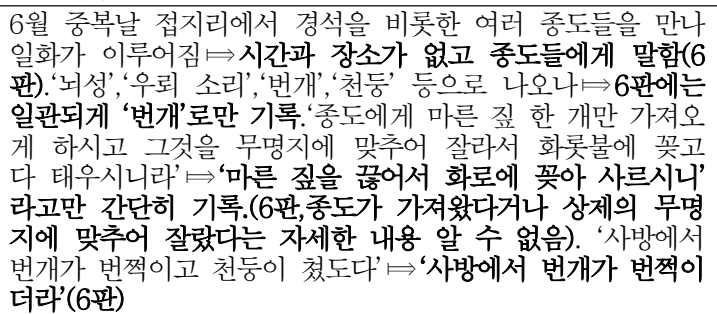 & $\begin{array}{l}\text { 시기와 장소가 } \\
\text { 『전경』에만 있음, } \\
\text { 내용차이 }\end{array}$ \\
\hline 18 & 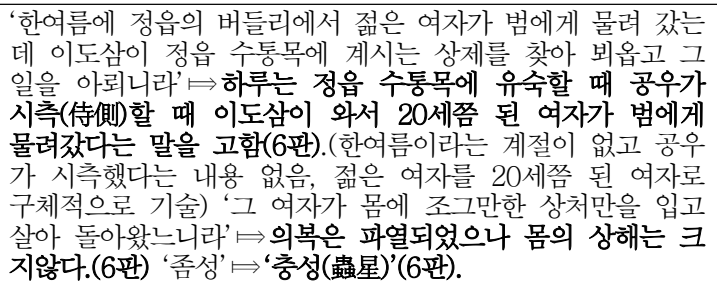 & 용어나 내용차이 \\
\hline 20 & 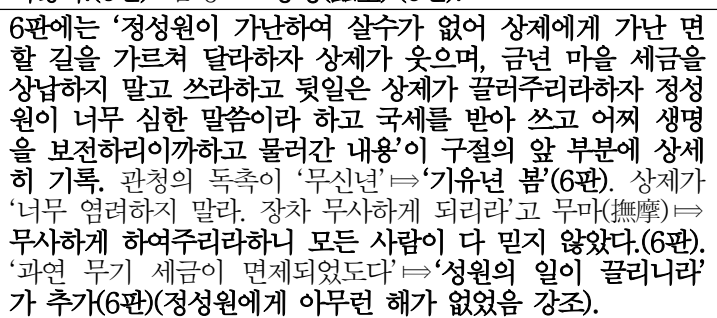 & $\begin{array}{l}\text { 시기가 다름. } \\
\text { 상세한 } \\
\text { 기록(6판). 종도 } \\
\text { 어려움 없음 } \\
\text { 강조(『전경』) }\end{array}$ \\
\hline
\end{tabular}

22절:(7-16) '주무시는 틈을 타서 방심하는 자에게 마음을 통찰하신 듯이 깨우쳐 주고 방심을 거두게 하시니라'가 6판에는 ‘주무실 때를 타 서 방심하는 자가 있을 지라도 문득 보시는 듯이 마음을 거두라고 명하 시니라'로 '마음을 통찰하신 듯이'가 간단히 '보시는 듯이'로 기술되어 있다. 23절:(2-127) 종도들이 태좌법으로 앉아 있을 때 조금도 움직이 
지 못한 것으로 되어 있으나 6판에는 상제가 명(命)한 것으로 되어 있 다. 23절의 끝 부분에는 '더욱 심신의 연마에 힘썼도다'라는 내용이 추 가되어 종도들이 깊이 깨달아 수행에 최선을 다했음을 강조하고 있다. 25절:(2-99) '번개가 번쩍이고 천둥이 천지를 진동하니라'가 6판에는 '우뢰가 크게 일어나며 천지가 진동하는지라'로 되어 있다. 27절:(9-21) 6 판에는 앞 부분에 갑칠에게 장령을 붙여 서양으로부터 우사를 넘겨 온 뒤에 류찬명이 이 묘한 법을 세상 사람이 다 알게 하소서라는 내용 이 있어 27절에 '상제께서 어느날 말씀하시되「너는 나로 하여금 오래 살기를 바라는도다」 하시고 글 한 수를 외우셨도다'에서 '너'가 류찬명 임을 알 수 있게 해주는 단서를 제공하고 있다. 한시에서 '稚子哭問母 何之'에서 '稚子'55)가 6판에는 “稚兒”56)로 되어 있고, “爲道靑山探藥䐅” 에서 ‘探藥”57)가 6판에서 ‘探菜”58)로 되어 있다. 28절:(2-76) 6판에는 섣달에 고부 와룡리에서 있었던 일화로 적혀 있다. '원일에게 「네가 동천에 붉은 옷을 입고 구름 속에 앉은 사람에게 네 번 절한 일이 있 었는데 기억이 있느냐고 회상을 촉구하시더니 원일이 문득 깨닫고 일어나 상제께 네 번 절하니 옆에 앉아있던 종도들이 까닭을 모르고 물으니라'로 되어 있으나 6판에는 상제가 신원일이 절한 대상이 상제 자신이라 하고 지금 다시 절하라고 한 것으로 되어 있다. 또 6판의 끝에는 '집안 사람들은 새 옷 입고 밖에 나가는 것을 해괴하게 여겼 다'는 내용이 추가되었다. 30절:(2-65) '이해 여름에 경석이 상제를 모셨도다라는 내용이 30절에는 앞 부분에 더 있다. 상제가 '내가 있 는 곳에서 비록 사소한 일이라도 헛된 일을 못하느니라. 저 하늘을 보 라'고 한 내용이 6 판에는 '저 허공을 보라 나는 모든 일을 함부로 하 기 어려우니'로 되어 있다. '구름과 같은 기운이 종도들이 놀고 있는 모양을 짓고 중천에 떠 있었도다'는 6판에서 '구름과 같은 이상한 기

55) 어린 아들.

56) 어린 아이.

57) 약초를 캐다.

58) 나물을 캐다. 
운이 가야금 타는 형상과 오륙인이 벌려 앉은 모형을 이루어 허공에 떠 있더라'로 되어 있다. 31절:(4-99) '무신년 시월'이 6판에는 '시월' 로만 되어 있다. 쌀을 깨끗하게 찧어서 약방에 저장하게 하였으나가 6 판에는 백미 스무 말을 약방에 들인 것으로만 되어 있다. 31절에는 쌀이 부족하여 아침밥을 지을 수 없어 반 말로 조반을 지었다는 것이 6 판에서는 쌀을 사용한 내용이 없이 '반 말을 갈라냈다'고 하여 다르 다. 32절:(2-102) 32절에는 '이해 겨울'로 시기가 적혀 있다. '이해 겨울은 몹시 춥고 날씨가 고르지 못하였으므로 덕찬이 크게 염려하였 으나 혼삿날은 봄과 같이 따뜻하므로 마음을 놓으니라'가 6판에는'일 기가 연일 험악하여 심히 염려하던 중인데 그 날에 이르러서는 뜻밖 에 온화하여지니라'로 적혀 있다. 32절에는 김덕찬의 염려하는 입장을 중심으로 기록되어 있고 '여러 사람이「상제의 부조를 받은 혼삿날이 라」고 칭송하였도다'는 내용이 문미(文尾)에 있어 상제의 날씨 부조를 더 강조하여 상제 권지(權智)의 의미를 부각하고 있다. 33절:(2-13)6 판에는 구름 기둥이 높이 서있다고 되어 있으나 33절에는 깃대와 같 이 높이 뻗쳐 있다고 나온다. 35절:(2-116) 6판에는 '유월에 구릿골 에 계실 때 하루는'으로 시간과 장소가 나타난다. '이때에 오랫동안 가물었도다'가 6판에는 '경학이 이르러 오랫동안 날이 가물어서 모를 옮기지 못하여 민심이 불안함을 아뢴대'로 되어 있어 경학이 등장하여 문제를 말하는 것이 다르다. 아울러 '상제께서 갑칠에게 청수 한 동이 를 길어오게 하신 후 일러 말씀하시기를 「아래와 웃옷을 벗고 물동이 앞에 합장하고 서 있어라 서양으로부터 우사를 불러와서 만인의 갈망 을 풀어 주리라.」갑칠이 말씀대로 옷을 벗고 동이 앞에 합장하여 서 니 문득 검은 구름이 사방에서 일어나고 큰 비가 내리니라'도 6판에 는 경학에게 '미리 양지 한축에 글을 가득히 써 두었던 것을 상제가 경학에게 내어주며 청수에 적시어 가루가 되게 부비라했으나 비가 오 지 않자, 상제가 갑칠에게 네게 장령(將令)을 붙여 서양으로부터 우사 를 불러 만인의 갈증을 풀어 주려했더니 갑칠이 어제 저녁에 상제의 
명을 어기고 잠을 자서, 비가오지 않아 옷을 벗고 청수 앞에 합장하고 서서 사죄하라 하여 갑칠이 명한 대로 하니 서쪽 하늘에서 검은 구름 이 일어나며 큰 비가 쏟아져 앞내가 창일(泥溢)한 것'으로 되어 있다. 또 이때 경학이 상제에게 이만하면 넉넉하겠나이다라고 말하여 '상제 가 부채를 한번 흔드니 비가 그친 것'으로 되어 있어 갑칠과 함께 경 학이 등장하고 내용이 자세하다. 이어서 35절에 '이때 상제께서 갑칠 에게「청수를 쏟고 옷을 입으라」하시고 종도들에게 이르시니라. 「너 희들도 지성을 다하여 수련을 쌓으면 모든 일이 뜻대로 되리라」’고 기 록되어 두 문헌의 내용이 유사하다. 다만 35절에는 '류찬명이 「이런 일은 세상 사람이 다 모르니 원컨대 세상 사람으로 하여금 널리 깨닫 게 하여 주소서」하고 아뢰었도다’라는 내용이 구절의 끝에 더 추가된 것이 6판과 차이가 난다. 37절:(5-13) '인세에 그것을 베풀고자 하였 으나'가 6판에는 '좋은 세상을 꾸미려하다가'로 되어 있다. 38 절: $(9-24,25)$ '네가 나의 사무를 담당하겠느냐'가 '대신 보겠느냐'로 적혀 있다. '재질이 둔박하와 감당치 못할까 하나이다'에 6판에는 '배 운 바가 없다'는 내용이 추가되었다. 이에 대해 38절에는 '대답하는 것을 들으시고 상제께서 꾸짖으시니 형렬이 대하여「가르치심에 힘입 어 담당하겠나이다」고 여쭈니'가 있으나 이 부분이 6판에는 없고, 6 판에는 다른 내용인 우순(虞舜)의 옛 일이 적혀 있다. 즉 '미유학양자 이후(未有學養子而後)에 가자야(嫁者也)라 우순(虞舜)이 역산(歷山)에 밭갈고 뇌택(雷澤)에 고기잡고 하빈(河濱)에 질점할때에 선기옥형(璿 璣玉衡)을 알지 못하였나니 당국(當局)하면 아느니라'는 긴 글이 기록 되며 6판 24절을 맺고 있다. 38절에는 '상제께서「무한유사지불명(無 恨有司之不明)하라. 마속(馬謖)은 공명(孔明)의 친우로되 처사를 잘못 함으로써 공명이 휘루참지(揮淚斬之)하였으니 삼가할 지어다」고 일러 주셨도다'라고 되어 있으나 6판은 '삼가할 지어다'가 없이 25절을 이 루고 있다. 
〈표 15〉「권지」편 2장 구절(22 38절) 내용요약 및 6판과의 비교

\begin{tabular}{|c|c|c|}
\hline 절 & 「권지」편 1장 구절의 6판과의 비교 내용 & 비고 \\
\hline 22 & $\begin{array}{l}\text { ‘주무시는 틈을 타서 방심하는 자에게 마음을 통찰하신 듯이 } \\
\text { 깨우쳐 주고 방심을 거두게 하시니라’ ‘주무실 때를 타서 } \\
\text { 방심하는 자가 있을 지라도 문득 보시는 듯이 마음을 거두 } \\
\text { 라고 명하시니라'(6판). '마음을 통찰하신 듯이' } \risingdotseq \text { 간단히 '보 } \\
\text { 시는 듯이'(6판) }\end{array}$ & 내용 차이 \\
\hline 23 & $\begin{array}{l}\text { 종도들이 태좌법으로 앉아 있을 때 조금도 움직이지 못함 } \\
\text { 상제가 명(命)한 것으로 되어 있음(6판). } 23 \text { 절의 끝 부분에 } \\
\text { 는 '더욱 심신의 연마에 힘썼도다'라는 내용 추가(종도들이 } \\
\text { 깊이 깨달아 수행에 최선을 다했음을 강조) }\end{array}$ & $\begin{array}{l}\text { 내용차이. } \\
\text { 내용추가(『전경』, } \\
\text { 수행(修行)강조) }\end{array}$ \\
\hline 25 & $\begin{array}{l}\text { ‘번개가 번쩍이고 천둥이 천지를 진동하니라’ ‘우뢰가 크 } \\
\text { 게 일어나며 천지가 진동하는지라'(6판)(표현상 약하게) }\end{array}$ & $\begin{array}{l}\text { 내용 및 } \\
\text { 어감(語感)차이 }\end{array}$ \\
\hline 27 & 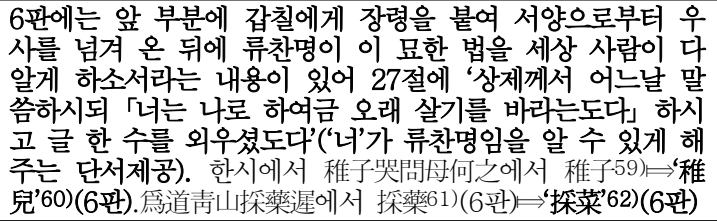 & $\begin{array}{l}\text { 내용에 대한 } \\
\text { 단서제공(6판). } \\
\text { 한자단어차이. }\end{array}$ \\
\hline 28 & $\begin{array}{l}\text { 6판에는 섣달에 고부 와룡리에서 있었던 일화. '원일에게 } \\
\text { 「네가 동천에 붉은 옷을 입고 구름 속에 앉은 사람에게 네 } \\
\text { 번 절한 일이 있었든데 기억이 있느냐고 회상을 촉구하시 } \\
\text { 더니 원일이 문득 깨닫고 일어나 상제께 네 번 절하니 옆에 } \\
\text { 앉아있던 종도들이 까닭을 모르고 물으니라' 상제가 신원 } \\
\text { 일이 절한 대상이 상제 자신이라 하고 지금 다시 절함.또 } 6 \\
\text { 판의 끝에는'집안 사람들은 새 옷 입고 밖에 나가는 것을 해 } \\
\text { 괴하게 여겼다는 내용 추가(6판). }\end{array}$ & $\begin{array}{l}\text { 내용차이. } \\
\text { 내용추가. }\end{array}$ \\
\hline 30 & 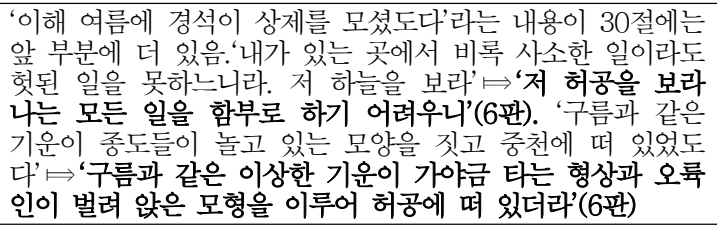 & $\begin{array}{l}\text { 내용추가 }(『 \text { 전경』 }) \\
\text { 내용차이 }\end{array}$ \\
\hline 31 & $\begin{array}{l}\text { ‘무신년 시월’ ‘시월’(6판). 쌀을 깨끗하게 찧어서 약방에 저 } \\
\text { 장하게 하였으납백미 스무 말을 약방에 들임(6판). 쌀이 부 } \\
\text { 족하여 아침밥을 지을 수 없어 반 말로 조반을 지음ㅆ쌀을 } \\
\text { 사용한 내용 없이 ‘반 말을 갈라냈다고 한 것과 다름(6판). }\end{array}$ & $\begin{array}{l}\text { 연도없음(6판) } \\
\text { 내용차이 }\end{array}$ \\
\hline 32 & $\begin{array}{l}\text { 32절에는 ‘이해 겨울’로 시기가 있음'이해 겨울은 몹시 춥 } \\
\text { 고 날씨가 고르지 못하였으므로 덕찬이 크게 염려하였으나 } \\
\text { 혼상날은 봄과 같이 따뜻하므로 마음을 놓으니라’”일기가 } \\
\text { 연일 험악하여 심히 염려하던 중인데 그 날에 이르러서는 } \\
\text { 뜻밖에 온화하여지니라'(6판)(32절에 김덕찬의 염려하는 입 } \\
\text { 장을 중심으로 기록)'여러 사람이상제의 부조를 받은 혼삿 } \\
\text { 날이라」고 칭송하였도다'는 내용이 문미(文尾)에 있음(상제 } \\
\text { 의 날씨 부조를 더 강조하여 상제 권지(權智)의 의미를 부 } \\
\text { 각, } 32 \text { 절) }\end{array}$ & $\begin{array}{l}\text { 시기가 } \\
\text { 있음(『전경』), } \\
\text { 내용차이 } \\
\text { (『전경』, 종도의 } \\
\text { 염려강조기술) }\end{array}$ \\
\hline
\end{tabular}




\begin{tabular}{|c|c|c|}
\hline 33 & $\begin{array}{l}\text { 33절에는 깃대와 같이 높이 뺃쳐 있다 } \Leftrightarrow 6 \text { 판에는 구름 기둥 } \\
\text { 이 높이 서있다고 되어 있음. }\end{array}$ & 내용차이 \\
\hline 35 & 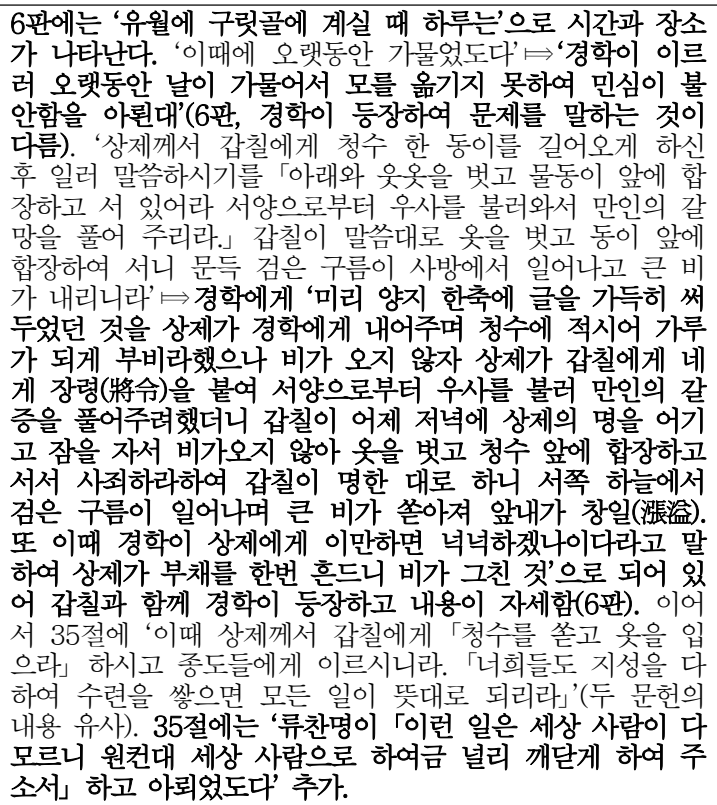 & $\begin{array}{l}\text { 시기와 장소가 } \\
\text { 있음(6판) 종도가 } \\
\text { 더 등장함(6판), } \\
\text { 내용추가(『전경』) }\end{array}$ \\
\hline 37 & $\begin{array}{l}\text { ‘인세에 그것을 베풀고자 하였으나’ } \risingdotseq \text { ‘좋은 세상을 꾸미려 } \\
\text { 하다가'(6판). }\end{array}$ & 내용차이 \\
\hline 38 & 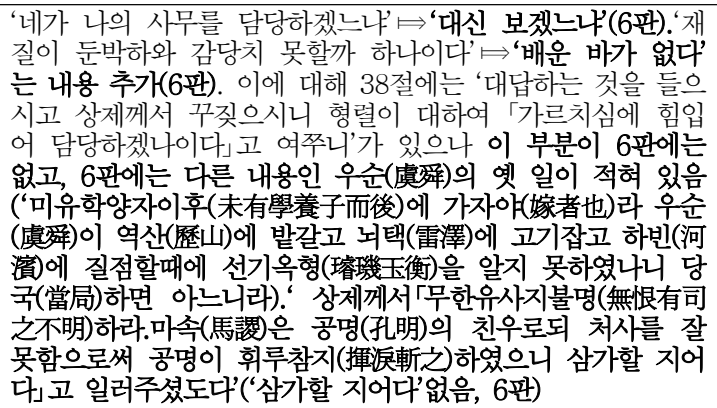 & $\begin{array}{l}\text { 내용차이, } \\
\text { 한문내용추가 } \\
\text { (6판) } \\
\text { 내용추가(『전경』, } \\
\text { 의미강조) }\end{array}$ \\
\hline
\end{tabular}

59) 어린 아들.

60) 어린 아이.

61) 약초를 캐다.

62) 나물을 캐다. 
이상에서 살펴본 『전경』「권지」편 1, 2장 구절들에 대해 이상호 (1888 1967)가 마지막으로 편저한 『대순전경』의 최종판인 6판(1965) 을 대비시켜 살펴 본 결과 다음과 같이 크게 정리된다. 1. 두 문헌에서 구절의 내용이 거의 같은 구절도 있다. 2. 각 문헌의 서술이 단어(單語) 나 몇 개 문장(文章)에서 차이가 나는 구절들도 등장한다. 3. 각 문헌의 구절의 연도가 차이가 나는 구절들이 보인다. 4. 기록의 내용상 두 문 헌의 각각에서 더 추가된 기록들도 발견된다.

\section{VI. 맺음말}

이글은 『전경(典經)』의 구절들을 통해 권지의 의미를 살펴보고, 다 른 편에 나타난 권지적 면모와 『전경』 각 편의 장(章)의 양상을 찾아 보았으며, 이어서「권지」편 각 구절들의 변모를『대순전경』6판과 비 교 대조하여 그 문헌학적 의미를 탐색할 목적으로 진행되었다. 상제가 한반도에 강세(降世)하여 광구천하(匡救天下)하기 위해 천지인 삼계에 대한 대(大) 권능(權能)으로 9년간 천지공사(天地公事)를 행하여 인류 에게 상제의 천지대도(天地大道)가 전해지고 지상에 무량극락(無量極 樂) 청화(淸華) 오만년(五萬年) 용화선경(龍華仙境)인 지상천국(地上天 國)이 이룩되는 것은 상제가 보여준 권능을 근간으로 천지공사가 삼 계(三界)에서 완수(完逐)되기 때문이다.

이글에서「권지」편 1장과 2장 구절들의 특성을 바탕으로 『전경』 「공사」편 1장에 나타난 상제 권지의 양상을 찾아본 후 구절의 변이 양 상을『대순전경』 6 판과 비교 연구한 결과를 요약해보면 다음과 같다.

첫째, 상제의 권지는 천지인 삼계에서 이루어져 천지공사(天地公事) 를 통해 후천선경(後天仙境)을 이루는 핵심적 요소가 됨을 정리 요약 된 구절들에서 볼 수 있다. 
둘째, 『전경』이 일곱 개의 편으로 나누어져 있지만, 「공사」편에 삼 계 대권에 대한 구절이 나타나듯이 일곱 개의 편에 천지인 삼계로 용 사된 상제의 권능이 나타난 관련 구절들이 분포되어 각 편의 제목이 나타내는 목적을 이루는 것으로 되어 있다. 이는 대표적으로 이글에서 본「공사」편 1장 구절을 보아도 드러난다.

셋째, 여러 개의 장으로 되어 있는 『전경』의 5 개 편에서의 장의 분 류에 대한 기준은「교법」을 제외하고 공통점은 연도별로 이루어졌다 는 것이다.「권지」편을 포함해서 다수의 장으로 이루어진 편에서 내용 상으로 보더라도 장 분류에 대한 규칙성은 특별히 찾을 수 없었다.

넷째, 『전경』「권지」편 1, 2장 구절들에 대해 이상호가 마지막으로 편저한 『대순전경』의 최종판인 6판(1965)을 대비시켜 살펴본 결과 다 음과 같이 크게 정리된다. 1 . 두 문헌에서 구절의 내용이 거의 같은 구절도 있다. 2. 각 문헌의 서술이 단어(單語)나 몇 개 문장(文章)에서 차이가 나는 구절들도 등장한다. 3. 각 문헌의 구절의 연도가 차이가 나는 구절들이 보인다. 4. 기록의 내용상 두 문헌의 각각에서 더 추가 된 기록들도 발견된다. 


\section{【참 고 문 헌 】}

『전경』, 여주: 대순진리회 출판부, 2010.

『대순진리회요람』, 여주: 대순진리회 교무부, 2010.

『대순전경』6판, 서울: 동도교 증산교회 본부, 1965.

『중용』

고남식, 「해원 주제 강증산 전승 연구」, 건국대학교 박사학위 논문, 2003. 『대순전경』초판 구절의 변이 - 초판 10장을 중심으로」, 『종교연 구』67, 2012. https://doi.org/10.21457/kars..67.201206.207

—, 『『전경』「행록」편 연구」, 『대순사상논총』 $32,2019$. https://doi.org/10.25050/jdaos.2019.32.0.31

ㄴ (『전경』「교운」편 1장에 나타난 교운의 의미와 구절의 변이 연구」, 『대순사상논총』36, 2020.

https://doi.org/10.25050/jdaos.2020.36.0.153

김탁, 『증산교의 교리 체계화 과정』, 한국정신문화연구원 석사학위 논문, 1986.

양은용, 「증산교의 성립과『증산천사공사기』, 『한국종교』30, 2006.

임영창, 「대순전경의 사적 의의」, 『증산사상연구』 $15,1989$.

조동일, 『한국문학통사』 4, 서울: 지식산업사, 1994. 


\section{- Abstract}

\section{A Study on the Gwon Ji (權智) of Jeon-gyeong}

\section{Ko Nam-sik}

Professor, Department of Daesoon Theology, Daejin University

The purpose of this study is to clarify the meaning of Gwonji (權智, Authority and Foreknowledge) through the phrases contained in the section, Gwonji of the Jeon-gyeong (known in English as The Canonical Scripture), and to compare the changes that each verse from Gwonji underwent by juxtaposing it against the sixth edition of Daesoon Jeong-gyeong (which was published prior to the Jeon-gyeong) to explore the term's literary meaning. In order to save the world, Sangje descended to human world and performed the Cheonjigongsa (Reordering Works of the Universe) for nine years with the power he exercises over the Three Realms of Heaven, Earth, and Humanity. Based on the plan set by the Cheonjigongsa, Sangje's teachings were spread to humanity and provided as the basis for building the earthly paradise. From this perspective, this study demonstrates its significance by providing a comprehensive approach to the Jeon-gyeong by highlighting the subject of Sangje's authority and wisdom as recorded in the section titled Gwonji. There is also value in the variant verses from Gwonji that the study discovered by comparing and analyzing the phrases from chapters one and two of 
Gwonji as they appear in the Jeon-gyeong with their equivalents from the sixth edition of Daesoon Jeong-gyeong, which was published in 1965, nearly a decade before Daesoon Jinrihoe's publication of the Jeon-gyeong in 1974. The results of this comparative study of parallel passages related to Gwonji are as follows: First, Gwonji can be understood as the authority and wisdom of Sangje, and this is the core element in realizing the Earthly Paradise through His Cheonjigongsa. Second, phrases related to Sangje's authority and wisdom are spread out in the seven sections of the Jeon-gyeong, and they were written to emphasize the main purpose suggested in each section or chapter. Third, in sections other than Gwonji, the great power of Sangje is exercised to treat matters related to deities and social problems, whereas in Gwonji part, it is dedicated to the performance of Cheonjigongsa. Fourth, there are five sections of the Jeon-gyeong which are organized into chapters. All of these sections and their chapters indicate the year when key events transpired. Fifth, when passages from chapter one of Gwonji is compared to parallel passages from Daesoon Jeon-gyeong, there are several verses that vary in terms of their wording and also sentences that indicate a different dates or times for certain events.

Keywords: Gwonji (權智), Great Authority over the Three Realms, Halting the Sun, Orders to Rule the Road 